\title{
Cross Talk Between Cellular Redox State and the Antiapoptotic Protein Bcl-2
}

\author{
Sebastian Öther-Gee Pohl,,,2 Mark Agostino,,-3 Arun Dharmarajan,1,2 and Shazib Pervaiz ${ }^{2,4-6}$
}

\begin{abstract}
Significance: B cell lymphoma-2 (Bcl-2) was discovered over three decades ago and is the prototype antiapoptotic member of the Bcl-2 family that comprises proteins with contrasting effects on cell fate. First identified as a consequence of chromosomal translocation (t 14:18) in human lymphoma, subsequent studies have revealed mutations and/or gene copy number alterations as well as posttranslational modifications of Bcl-2 in a variety of human cancers. The canonical function of Bcl-2 is linked to its ability to inhibit mitochondrial membrane permeabilization, thereby regulating apoptosome assembly and activation by blocking the cytosolic translocation of death amplification factors. Of note, the identification of specific domains within the Bcl-2 family of proteins (Bcl-2 homology domains; $\mathrm{BH}$ domains) has not only provided a mechanistic insight into the various interactions between the member proteins but has also been the impetus behind the design and development of small molecule inhibitors and $\mathrm{BH} 3$ mimetics for clinical use.

Recent Advances: Aside from its role in maintaining mitochondrial integrity, recent evidence provides testimony to a novel facet in the biology of Bcl-2 that involves an intricate cross talk with cellular redox state. Bcl-2 overexpression modulates mitochondrial redox metabolism to create a "pro-oxidant" milieu, conducive for cell survival. However, under states of oxidative stress, overexpression of Bcl-2 functions as a redox sink to prevent excessive buildup of reactive oxygen species, thereby inhibiting execution signals. Emerging evidence indicates various redox-dependent transcriptional changes and posttranslational modifications with different functional outcomes.

Critical Issues: Understanding the complex interplay between Bcl-2 and the cellular redox milieu from the standpoint of cell fate signaling remains vital for a better understanding of pathological states associated with altered redox metabolism and/or aberrant Bcl-2 expression.

Future Directions: Based on its canonical functions, Bcl-2 has emerged as a potential druggable target. Small molecule inhibitors of Bcl-2 and/or other family members with similar function, as well as BH3 mimetics, are showing promise in the clinic. The emerging evidence for the noncanonical activity linked to cellular redox metabolism provides a novel avenue for the design and development of diagnostic and therapeutic strategies against cancers refractory to conventional chemotherapy by the overexpression of this prosurvival protein. Antioxid. Redox Signal. 00, 000-000.
\end{abstract}

Keywords: B cell lymphoma 2, Bcl2, reactive oxygen species, ROS, oxidative stress, BH domains

\footnotetext{
${ }^{1}$ Stem Cell and Cancer Biology Laboratory, Curtin Health and Innovation Research Institute, Curtin University, Bentley, Western Australia.

${ }^{2}$ School of Biomedical Sciences and ${ }^{3}$ Curtin Institute for Computation, Curtin University, Perth, Western Australia.

${ }^{4}$ Department of Physiology, Yong Loo Lin School of Medicine and ${ }^{5}$ NUS Graduate School for Integrative Sciences and Engineering, National University of Singapore, Singapore, Singapore.

${ }^{6}$ National University Cancer Institute, National University Health System, Singapore, Singapore.
} 


\section{Introduction}

B cell lymphoma 2: the founding member of a functionally disparate family

B CELL LYMPHOMA 2 (Bcl-2) is the prototypical Bcl-family protein and a major regulator of cell death. Bcl-2 was discovered following the cloning of leukemic cells bearing the $\mathrm{t}(14 ; 18)(\mathrm{q} 32 ; \mathrm{q} 21)$ chromosome translocation (175). Subsequent chromosome mapping identified BCL2 as a putative gene involved in the pathogenesis of B cell and follicular lymphomas (174). McDonnell et al. (115) demonstrated that this interchromosomal translocation resulted in the overexpression of Bcl-2 and extended the life span of B cells.

Bcl-2 is primarily localized in the mitochondria (67), however, its localization has also be extended to the nucleus and endoplasmic reticulum (ER). Functionally, Bcl-2 is characterized as an antiapoptotic protein due to its role in inhibiting proapoptotic proteins; these include the $\mathrm{Bcl}-2$ family members Bak and Bax (28). On apoptotic stimulation, death receptor- or drug-induced, a cascade of caspase activation results in the induction of mitochondrial outer membrane permeabilization (MOMP). In the case of death receptor signaling, direct executioner caspase activation is induced in certain cell types where the death initiating signaling complex is efficiently formed (Type 1 or extrinsic pathway); however, in other cell types, the initiator caspase activation is relatively weak to autonomously engage the executioner caspase(s), and therefore, the signal is routed through the mitochondria for efficient death execution (Type 2 or intrinsic signaling). The latter is also the preferred mode of execution triggered on exposure of cells to DNA damaging agents, $\gamma$-irradiation, as well as other forms of chemotherapy. Importantly, the recruitment of mitochondria is a function of the proapoptotic members of the Bcl-2 family that, on apoptotic stimulation, translocate to the mitochondria forming oligomeric complexes (40) that compromise the permeability of the outer membrane (15), thereby facilitating the egress of death amplification factors such as cytochrome $c(83), \mathrm{Smac} /$ direct IAP binding protein with low pI (DIABLO) (1), and apoptosis inducing factor (75). The antiapoptotic members of the Bcl-2 family, in particular Bcl-2 and Bcl-xL, prevent MOMP by competing with and inhibiting the oligomerization of the proapoptotic members, such as Bax and Bak $(117,135$, 190). As such, the apoptosis inhibitory function of Bcl-2 is strongly associated with the Type 2 death signaling pathway (Fig. 1).

Bcl-2 expression has also been shown to regulate autophagy, a process of self- consumption induced on starvation or other stress states. Autophagy has emerged as a central player in the removal of damaged organelles as well as a source of nutrients for cells under starvation, hence the association with a prosurvival phenotype. Autophagy has also been linked to cell death signaling in response to certain noxious stimuli. Interestingly, being a survival promoting protein, Bcl-2 has also been shown to have a critical role in regulating autophagy (97). Pattingre et al. demonstrated the antiautophagic role of Bcl-2, promoting cell survival, which was dependent on its interaction with Beclin1 (139). This interaction utilized the $\mathrm{BH} 1$ and $\mathrm{BH} 2$ domains of Bcl-2. Beclin1 expression is low to absent in many cancer cells, leading to loss of autophagy and promotion of cell survival. Cancer cells expressing Beclin1 exhibited higher levels of LC3-induced autophagy, which was inhibited upon overexpression of Bcl2. The expression of Bcl-2 mutants (G145A/W188A) resulted in the loss of Bcl-2:Beclin1 interaction, as well as the initiation of cellular autophagy. Interestingly, this was only observed when Bcl-2 was localized to the ER, not the mitochondria (139). The interaction was also found to be dependent on JNK1-mediated phosphorylation of Thr69, Ser70, and Ser87. This starvation-dependent phosphorylation resulted in a dissociation of Beclin1 from Bcl-2 and the induction of autophagy (182) (Fig. 2). The inhibitory effect of Bcl-2 on apoptosis and autophagy lends credence to the hypothesis that apoptosis and autophagy work in tandem to regulate processes involved in cellular transformation and its progression.

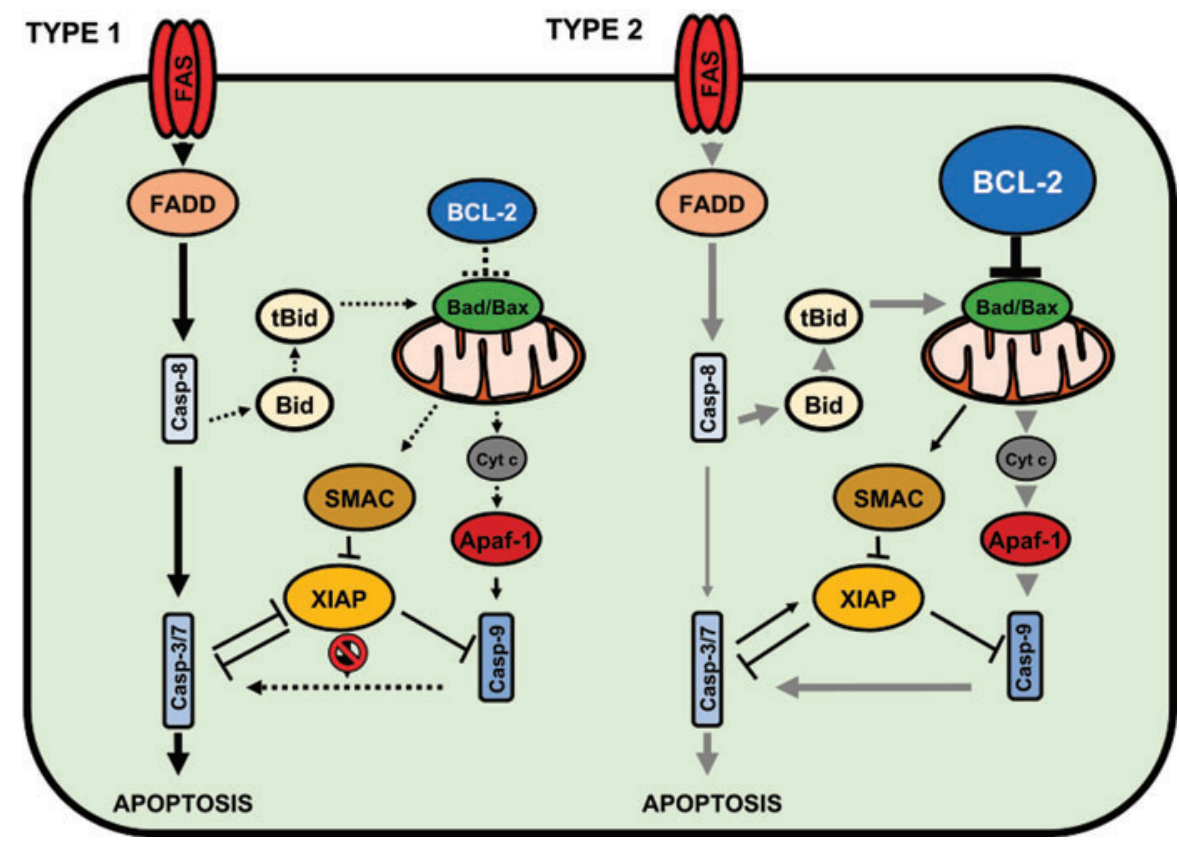

FIG. 1. Schematic of type 1 and type 2 death receptor pathways. Type 1 (bold black line) FAS (CD95) death signaling pathway signals independent of the intrinsic pathway. Following FAS ligand binding, signals are transduced through FADD-mediated caspase-8 activation and caspase-3/7 activation for cells to go under apoptosis. Type 2 (bold gray line) death signaling through FAS is directed through caspase-8-mediated Bid activation. Bcl-2 is the primary inhibitor of antiapoptosis in type 2 signaling. Bad/Bax can direct apoptosis by the release of cytochrome $c$, and the activation of Apaf- 1 and caspase-9. Dotted lines indicate no pathway involvement. Bcl-2, B cell lymphoma 2 . To see this illustration in color, the reader is referred to the web version of this article at www .liebertpub.com/ars 


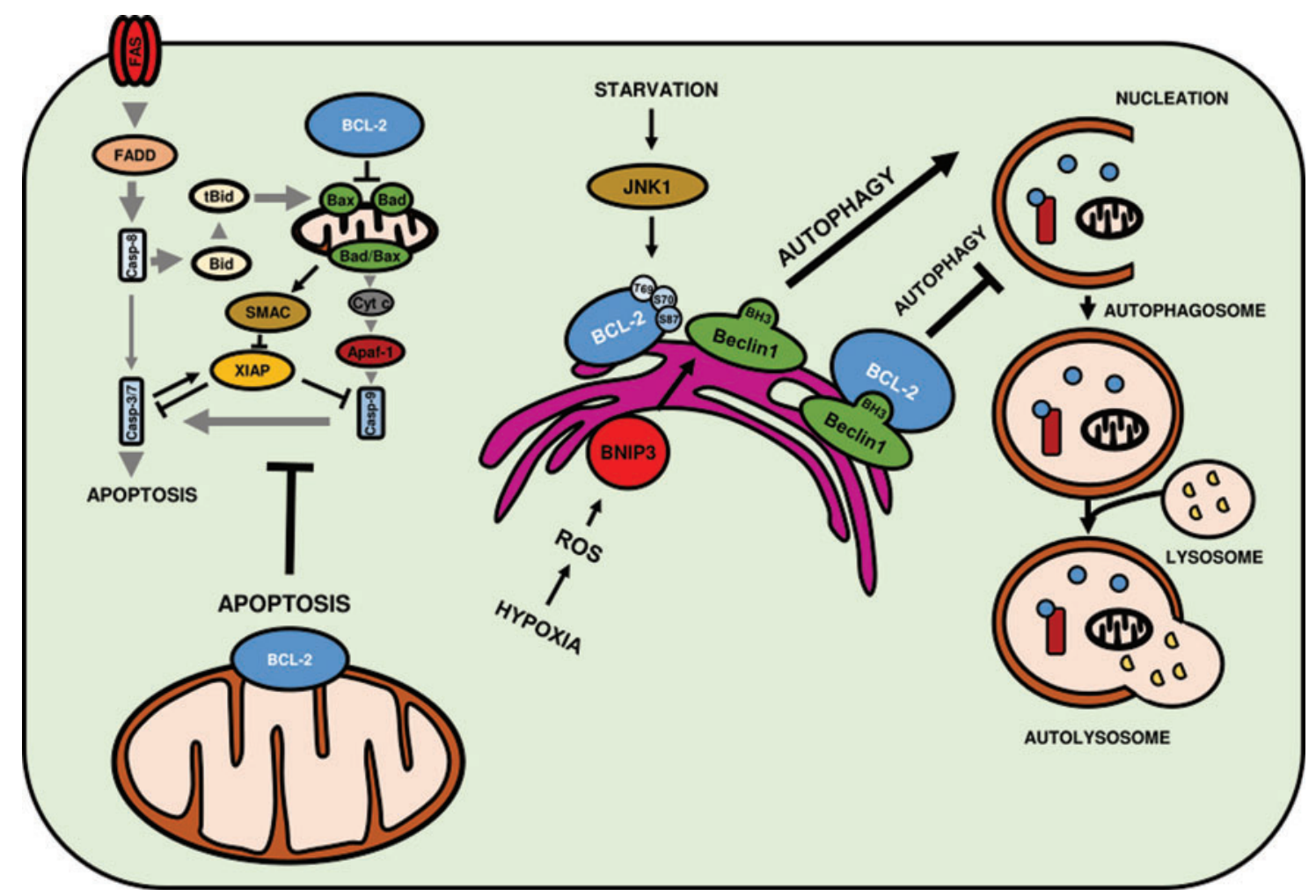

FIG. 2. Schematic of Bcl-2 role in apoptosis and autophagy. Bcl-2 localized to the ER directly interacts with Beclin 1 to inhibit autophagy. Starvation induced JNK1 activation leads to phosphorylation of Thr69, Ser70, and Ser87 of Bcl-2 disrupting the interaction with Beclin1 to induce autophagy. Interaction between the BH3 domains of Beclin1 and Bcl-2 results in the inhibition of autophagy. BNIP3 can interrupt the interaction between Bcl-2 and Beclin1 under conditions of hypoxia-induced ROS inducing autophagy. The autophagy pathway consists of nucleation, autophagosome assembly followed by fusion with the lysosome to result in the formation of an autolysosome. Bad/Bax forms heterodimers with Bcl-2 causing its inactivation and the initiation of apoptosis. $\mathrm{BH}, \mathrm{Bcl}-2$ homology domains; BNIP3, Bcl-2/adenovirus E1B 19-kDa protein-interacting protein 3; JNKs, c-Jun N-terminal kinases. To see this illustration in color, the reader is referred to the web version of this article at www.liebertpub.com/ars

Expression in cancer and mutational landscape. Genomic alterations in $B C L 2$ are common in a variety of cancers. Data sets obtained from The Cancer Genome Atlas (TCGA) accessed by cBioPortal $(24,53)$ revealed a high percentage of copy number alterations across the majority of cancers surveyed. In this regard, gene amplifications and deletions are the primary alterations (Fig. 3A). Unsurprisingly, amplifications and mutations occurred with higher frequencies in $\mathrm{B}$ cell lymphomas. The expression of $B C L 2 \mathrm{mRNA}$ was also determined by accessing the same data sets across 21 cancer types. Bcl-2 is not a ubiquitously expressed protein and there seems to be no correlation between organ systems and Bcl-2 expression in cancers, although hematopoietic and lymphoid malignancies were consistently high (Fig. 3B). Although $B C L 2$ expression was low in carcinomas of the bladder and testicular cancer, it still holds promising predictive power for outcomes in patients $(35,44)$. Interestingly, the lowest expression was found in hepatocellular carcinoma, where numerous studies have implicated its role as delaying the progression of carcinogenesis by delaying cell cycle progression $(148,177)$.

The mutational landscape of $B C L 2$ extends to both hematopoietic and nonhematopoietic tumors. To assist the interpretation of the likely impact of these mutations on Bcl-2 function, we have prepared a putative Bcl-2 homodimer model, based on the crystal structure complex of Bcl-2 with a
Bax BH3 peptide (PDB 2XA0) (86), the solution structure of Bcl-xL in its p53-bound conformation (PDB 2ME8) (50), and the crystal structure of the Bcl-xL domain-swapped homodimer (PDB 2B48) (131) (Fig. 3C). Characteristic gain of copy number and expression in diffuse large B cell lymphoma has been associated with $\mathrm{R} 129 \mathrm{H}$ missense mutation. In the putative Bcl-2 homodimer, Arg 129 appears to facilitate BH2 domain swapping; R129H may facilitate this more efficiently. The G128E mutation was identified in stomach cancer, although was not associated with a variation in copy number. This residue is on the Bcl-2 surface and is not involved in interactions; therefore, the influence of the Gly128 mutation on $\mathrm{Bcl}-2$ function is unclear from the structure.

Numerous G47S mutations have been identified in stomach cancer. Gly47 is located in the large unstructured loop region between the $\mathrm{BH} 4$ and $\mathrm{BH} 3$ domains and occurs at the dimer interface in the domain-swapped homodimer; G47S would likely enhance homodimer stability. Mutations in melanoma include T96I and A224 V. Thr96 is located at the dimer interface; T96I will likely enhance homodimer stability. Ala224 is located in the TM region of Bcl-2; A224 V will likely embed in the membrane more efficiently. A more comprehensive overview of the mutational landscape is accessible from the TCGA. Further probing of the functional relevance of mutations in $B C L 2$ is required for the significance in various disease contexts. 


\section{ㅇํㅇ}

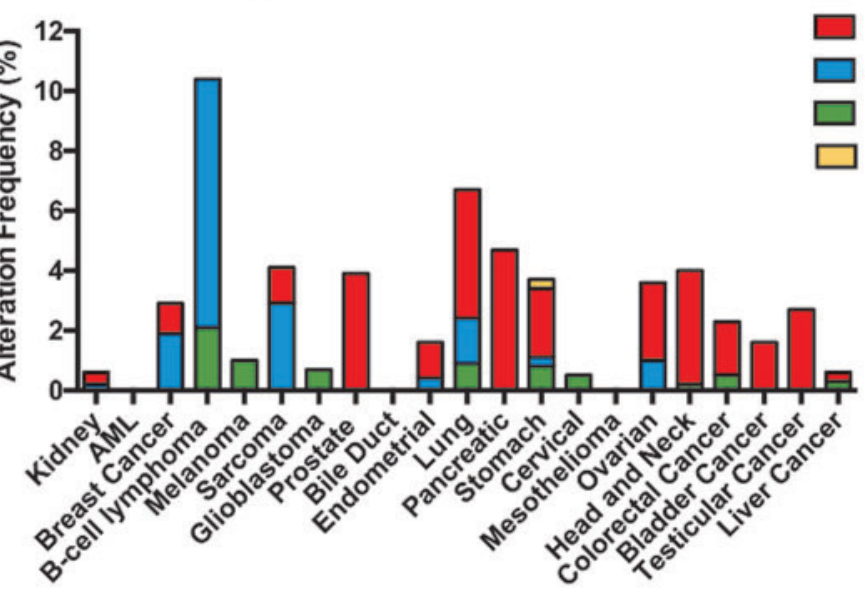

Deletion

Amplification

Mutation

Multiple Alterations

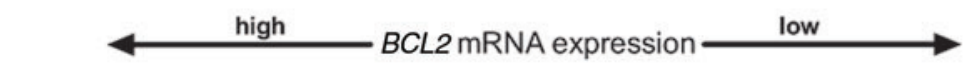

B BCL2 mRNA Expression TCGA Data Set


FIG. 3. BCL2 gene expression, mutational landscape, and copy number variations in cancer. (A) TCGA data sets retrieved from cBioPortal indicate copy number and mutation alterations across 21 cancer types. Deletions $(r e d)$, amplifications (blue), mutations (green), and multiple alterations (yellow) are shown as their alteration frequency in cancers sorted from high $B C L 2$ mRNA expression to low BCL2 mRNA expression. (B) BCL2 mRNA expression across 21 cancer types from TCGA data sets retrieved from cBioPortal. (C) Putative homodimer structure of Bcl-2 bound to Bax BH3 peptide with mutations highlighted. Color guide: blue - Bcl-2 molecule 1; green - Bcl-2 molecule 2; yellow - Bax BH3 peptides; violet - mutations identified in TCGA (not visible/highlighted: Gly47 in Bcl-2 molecule 1, Gly128 in either Bcl-2 molecule). TCGA, The Cancer Genome Atlas. To see this illustration in color, the reader is referred to the web version of this article at www.liebertpub.com/ars 


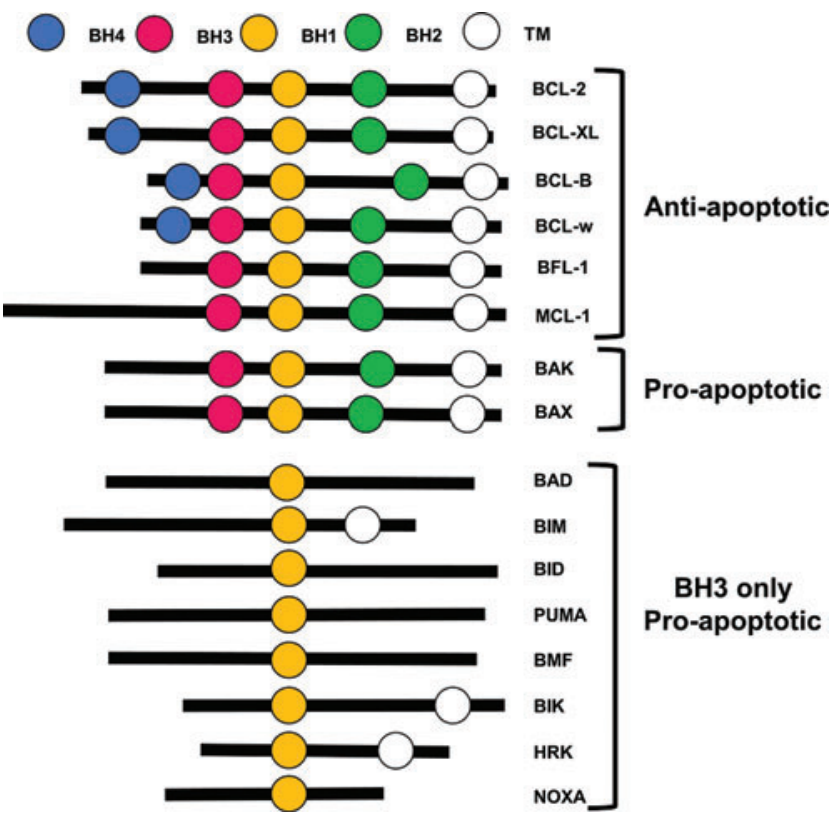

FIG. 4. Schematic view of Bcl-2 family proteins. To see this illustration in color, the reader is referred to the web version of this article at www.liebertpub.com/ars

Structural knowledge of Bcl-2 and its interactions with peptides and small molecule inhibitors. The structure of Bcl-2 family proteins has been extensively characterized by X-ray crystallography and NMR spectroscopy, and in the majority of cases, structural details of interactions with other proteins and prospective inhibitors are known. Bcl-2 family proteins are characterized by the presence of one or more $\mathrm{BH}$ domains. The $\mathrm{BH} 3$ domain is the most highly conserved, being present in all members of the Bcl-2 antiapoptotic multidomain, proapoptotic multidomain, and $\mathrm{BH} 3$-only domain members (Fig. 4). The antiapoptotic members contain all BH1BH4 domains, except MCL-1 (induced myeloid leukemia cell differentiation protein) and $\mathrm{A} 1$, which lack the $\mathrm{BH} 4$ motif. Bcl-2 itself features four $\mathrm{BH}$ domains (in sequence order, $\mathrm{BH} 4, \mathrm{BH} 3, \mathrm{BH} 1$, and $\mathrm{BH} 2$ ), which facilitate protein/protein interactions with proteins from and outside of the Bcl-2 family. The majority of the family proteins, excluding some of the BH3-only members (Bad, Bmf, Bid, Puma, and Noxa), possess a TM domain that is critical for homo- and heterooligomerization at the mitochondrial membrane $(135,191)$.

The structure of $\mathrm{Bcl}-2$ was first determined by NMR spectroscopy using a Bcl-2 construct, in which the loop between the $\mathrm{BH} 4$ and $\mathrm{BH} 3$ motifs was replaced by the equivalently located and shorter loop from the related protein Bcl-xL (146). This construct has been used to provide the majority of Bcl-2 structures (Table 1). The overall structural similarity of Bcl-2 to Bcl-xL, the native (119) and peptidebound $(147,161)$ structures of which were already known at the time, was revealed and provided the first indications as to the different peptide binding specificities of the two proteins.

The structure of Bcl-2 has since been resolved with a small range of peptide interactors, including fragments from naturally occurring proteins as well as designed peptides (Table 1). In all cases, binding is achieved via an $\alpha$-helix $(13,74,86)$ or $\alpha$-helix-like (25) structure interacting with a groove formed by the $\mathrm{BH} 3, \mathrm{BH} 1$, and $\mathrm{BH} 2$ domains (Fig. 5). Furthermore, peptides are oriented within the groove in the same way in all structures, with the $\mathrm{N}$-terminal oriented

Table 1. Experimentally Determined Bcl-2 Structures

\begin{tabular}{|c|c|c|c|c|c|}
\hline$P D B I D^{\mathrm{a}}$ & Method & Resolution $(\AA)$ & $\begin{array}{l}\text { Resolved portion } \\
\text { of structure }\end{array}$ & Bound molecules ${ }^{\mathrm{c}}$ & Reference \\
\hline $1 \mathrm{G} 5 \mathrm{M}$ & NMR & N/A & $3-34,92-207$ & None & $(146)$ \\
\hline $1 \mathrm{GJH}$ & NMR & N/A & $3-34,92-207$ & None & (146) \\
\hline 1YSW & NMR & N/A & $3-34,92-207$ & $\begin{array}{l}\text { 2-phenethylbenzothiazole analog } \\
\text { of Compound } \mathbf{1}\end{array}$ & $(134)^{\mathrm{d}}$ \\
\hline $2 \mathrm{O} 21$ & NMR & N/A & $3-34,92-207$ & $\begin{array}{l}\text { 2-phenethylbenzothiazole analog } \\
\text { of Compound } \mathbf{1}\end{array}$ & $(18)^{\mathrm{d}}$ \\
\hline $2 \mathrm{O} 22$ & NMR & N/A & $3-34,92-207$ & Compound $\mathbf{1 b}$ & $(18)^{\mathrm{d}}$ \\
\hline $2 \mathrm{O} 2 \mathrm{~F}$ & NMR & N/A & $3-34,92-207$ & Compound 43a & $(18)^{\mathrm{d}}$ \\
\hline $2 \mathrm{~W} 3 \mathrm{~L}$ & X-ray & 2.10 & $9-35,92-203$ & Phenylpyrazole 2 & (149) \\
\hline $2 \mathrm{XA0}$ & X-ray & 2.70 & $10-31,92-206$ & Bax $\mathrm{BH} 3$ peptide & $(86)$ \\
\hline 4AQ3 & X-ray & 2.40 & $9-31,92-203$ & Compound 18 & (141) \\
\hline 4IEH & X-ray & 2.10 & $9-31,92-204$ & Compound 6 & $(173)$ \\
\hline $4 \mathrm{LVT}$ & X-ray & 2.05 & $9-32,92-204$ & Navitoclax (ABT-263) & $(167)^{\mathrm{d}}$ \\
\hline $4 \mathrm{LXD}$ & X-ray & 1.90 & $6-33,92-204$ & Compound 2 & $(167)^{\mathrm{d}}$ \\
\hline 4MAN & X-ray & 2.07 & $8-29,92-204$ & Indole analog of compound $\mathbf{2}$ & $(167)^{\mathrm{d}}$ \\
\hline 5AGW & X-ray & 2.69 & $8-31,92-204$ & $\alpha / \beta-1$ & $(25)$ \\
\hline 5AGX & X-ray & 2.24 & $8-32,92-204$ & $\alpha / \beta$-1-LIN & $(25)$ \\
\hline $5 \mathrm{FCG}$ & $\mathrm{X}$-ray & 2.10 & $6-34,92-203$ & Peptide from HBx protein & $(74)$ \\
\hline $5 J S N$ & $\mathrm{X}$-ray & 2.10 & $7-32,87-207$ & $\alpha \mathrm{BCL} 2$ peptide & $(13)^{\mathrm{d}}$ \\
\hline
\end{tabular}

${ }^{a}$ All structures obtained from Bcl-2:Bcl-x $(\mathrm{L})$ chimera except 2XA0, 5FCG, and 5JSN, which were determined from full-length Bcl-2.

${ }^{\mathrm{b}}$ All structures have been determined from the Bcl-2 construct in which the BH4-BH3 loop of Bcl-2 replaced with shorter loop from Bcl$\mathrm{xL}$, except PDB 5JSN. In the NMR structures, the structure resolved is continuous; the replaced loop is largely not resolved in X-ray.

${ }^{\mathrm{c}}$ To avoid long systematic names, compounds are named according to their designation in their original publication; see the original publication cited in the corresponding row of the Reference column for specific compound details.

${ }^{\mathrm{d}}$ This study also reports ligand complexes with Bcl-xL; see the respective publication for further details.

Bcl-2, B cell lymphoma 2; BH, Bcl-2 homology domains; N/A, not applicable. 




FIG. 5. Overview of the structural basis of Bcl-2 recognition of peptides. (A) Bcl-2 in complex with Bax BH3 peptide (PDB 2XA0). Bcl-2 shown as a surface, with the BH4 (blue), BH3 (magenta), BH1 (yellow), and BH2 (green) motifs highlighted. Bax $\mathrm{BH} 3$ peptide shown in cartoon view, colored as a blue to red rainbow from the $\mathrm{N}$ to the $\mathrm{C}$ terminus. (B) Electrostatic potential surface of Bcl-2 in complex with Bax BH3 peptide (yellow). Hydrophobic residues of the Bax BH3 peptide interacting with Bcl-2 shown as transparent spheres. Electrostatic potential shown as a red-white-blue gradient, from negative (red) to neutral (white) to positive (blue). (C) The three major binding sites within the Bcl-2 binding groove. (D) Hydrogen bonding interactions observed in the Bax BH3 complex with Bcl-2. Asn 143 and Arg 146 of Bcl-2, and Asp68 of Bax $\mathrm{BH} 3$ labeled in italics and underlined to indicate that these residues are involved in hydrogen bonds replicated in the majority of peptide complexes with Bcl-2. Electrostatic potential calculated using the PDB2PQR/APBS web server; figures generated in PyMOL. To see this illustration in color, the reader is referred to the web version of this article at www.liebertpub.com/ars

toward the $\mathrm{BH} 1$ domain and the $\mathrm{C}$-terminal oriented toward the $\mathrm{BH} 2$ domain; peptide binding to $\mathrm{Bcl}-\mathrm{xL}$ also displays the same directionality in all cases $(7,49,93,94,132)$. Peptide binding to Bcl-2 appears largely mediated by a series of up to five hydrophobic residues (typically branched-chain amino acids) on one face of the peptide helix interacting with hydrophobic pockets along the Bcl-2 binding groove; this feature is present in all peptides cocrystallized with $\mathrm{Bcl}-2$, both naturally derived and designed peptides. Three hydrophobic pockets of Bcl-2 with which peptides interact may be defined: a large pocket formed largely by BH1-derived residues (herein referred to as the "BH1 pocket"; Leu119, Val133, Leu137, Ala149, and Phe153), a smaller pocket formed from near the end of the BH3 domain (herein referred to as the "near-BH3 pocket"; Phe104, Tyr108, and Phe112), and a second large pocket formed from residues from the $\mathrm{BH} 3, \mathrm{BH} 1$, and $\mathrm{BH} 2$ domains (herein referred to as the "BH2-incorporating pocket'; Ala100, Phe104, Trp144, Val148, Phe198, Leu201, and Tyr202). Peptides engaging all three pockets generally bind, from $\mathrm{N}$ to $\mathrm{C}$ terminal, the $\mathrm{BH} 1$ pocket with the most $\mathrm{N}$ terminal hydrophobic residues (1-2 residues), the near-BH3 pocket with the middle hydrophobic residue, and then, the $\mathrm{BH} 2$-incorporating pocket with the final hydrophobic residues (1-2 residues). The $\mathrm{HBx}$-derived peptide primarily engages the $\mathrm{BH} 1$ pocket, while the $\alpha \mathrm{BCL} 2$ peptide uses a single leucine to engage the $\mathrm{BH} 1$ and near- $\mathrm{BH} 3$ pockets. In addition, a range of supporting hydrogen bonds are present in each structure, however, just two are present in all structures (except the HBx complex); these are the interactions of an acidic residue (typically aspartate) between the hydrophobic residues engaging the $\mathrm{BH} 1$ and $\mathrm{BH} 2$-incorporating pockets with Asn143 and Arg 146 of Bcl-2. As the majority of hydrogen bonds in the peptide complexes with Bcl-2 are solvent exposed, these may be transient in typical cellular conditions. These hydrogen bonds are not replicated in any of the small molecules structurally characterized in complex with Bcl-2.

The structure of Bcl-2 has also been extensively characterized in complex with prospective small molecule inhibitors 
(Table 1) $(18,134,141,149,167,173)$. Due to the similarities between the Bcl-2 and Bcl-xL binding pockets, many of these inhibitors have also been structurally characterized in complex with Bcl-xL; achieving selectivity for Bcl-2 over Bcl-xL is a major challenge in the design of clinically useful $\mathrm{Bcl}-2$ inhibitors (8). Inhibitors structurally characterized in complex with Bcl-2 typically engage Bcl-2 in a remarkably similar way to the peptides, featuring long structures capable of binding to all three of the major pockets of the Bcl-2 binding groove; this also gives the majority of inhibitors molecular weights well over $500 \mathrm{Da}$, outside the typical range for small molecule drugs (103). Most inhibitors feature a small hydrophobic group, typically a single aromatic ring, bound to the $\mathrm{BH} 1$ pocket, a relatively straight structure comprising two rings connected in series, followed by a sulfonamide, lying between the $\mathrm{BH} 1$ and $\mathrm{BH} 2$-incorporating pockets, and a large flexible hydrophobic group interacting with the BH2-incorporating pocket (Fig. 6); these molecular features are largely carried over from the prototypical Bcl-2 inhibitor, ABT-737 (discussed in further detail in section IV: A Brief Overview of Bcl-2 Inhibitors: Past, Present, and Future). An exception to this is phenylpyrazole 2 (149), which does not engage the $\mathrm{BH} 2$-incorporating pocket; despite this, phenylpyrazole 2 exhibits $\sim 10$-fold selectivity for Bcl-2 over Bcl$\mathrm{xL}$, although its overall potency is eclipsed by ABT-737. Further modification of phenylpyrazole 2 yielded compound 18 (141), which does extend to the BH2-incorporating pocket and displays overall greater structural similarity to ABT-737.

\section{Reactive oxygen species and their role in cell signaling}

Reactive oxygen species (ROS) collectively refer to oxygen-derived $\left(\mathrm{O}_{2}\right)$ free radical and nonradical species (31). Radical ROS include superoxide anion $\left(\mathrm{O}_{2}{ }^{-}\right)$, hydroxyl

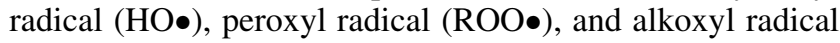
(RO•) (61). Nonradical ROS include hydrogen peroxide $\left(\mathrm{H}_{2} \mathrm{O}_{2}\right)$ and peroxynitrite $\left(\mathrm{ONOO}^{-}\right)(153,172)$. A tight balance between intracellular ROS and ROS regulating systems is critical for maintaining cellular homeostasis (38). Therefore, excessive generation of ROS or deficient antioxidant capacity alters cellular redox state with profound effects on cell growth, proliferation, and survival. Homeostatic levels of ROS are maintained by both enzymatic and nonenzymatic antioxidants. A depletion or overexpression of these antioxidants can alter cell fate. For example, overexpression of antioxidant enzyme SOD2 can protect cells from tumor necrosis factor (TNF)-induced apoptosis (110). This protected the cell from $\mathrm{H}_{2} \mathrm{O}_{2}$-induced cell death and promoted cell survival. On the contrary, SOD1 has been shown to be a potential therapeutic target in some cancers (56). These contrasting roles for similar antioxidant enzymes demonstrate that the tight balance of ROS levels can determine whether cells will survive or undergo apoptosis. The dogmatic view that any increase in intracellular ROS is linked to cell injury and death has been challenged by substantial experimental evidence attributing a secondary messenger function to a mild increase in ROS or a "pro-oxidant" milieu. Alterations in the cellular redox metabolism is linked to aging (105) as well as a host of pathological states, such as cancer (102), Alzheimer's disease (112), Parkinson's disease (29), diabetes (71), atherosclerosis (62), nonalcoholic fatty liver disease (17), and asthma (43).

Intracellular sources of ROS. The mitochondrion serves as an important source of intracellular ROS [elegantly reviewed in (30)], mainly generating $\mathrm{O}_{2}{ }^{-}$from Complex I (NADH dehydrogenase) (60) and Complex III (cytochrome $c$ reductase) (120), when electrons derived from NADH or $\mathrm{FADH}_{2}$ leak out on to and reduce molecular oxygen (121). The mitochondrial $\mathrm{O}_{2}{ }^{-}$levels are regulated by the action of manganese superoxide dismutase (MnSOD) in the inner matrix that generates $\mathrm{H}_{2} \mathrm{O}_{2}$ in the process (118). $\mathrm{H}_{2} \mathrm{O}_{2}$ in turn can be scavenged by catalase, glutathione peroxidases, and peroxiredoxins (85). A second important site of $\mathrm{O}_{2}{ }^{-}$- generation, best exemplified in phagocytic cells, is the NADPH oxidase (NOX) family of enzymes. NOX enzymes are made up of six subunits: a Rho guanosine triphosphatase (GTPase) and five phagocytic oxidase subunits (gp91, p22phox, p40phox, p47phox, and p67phox) (91). Additional sources of ROS include $\mathrm{O}_{2}{ }^{-}$from xanthine oxidases (88), cyclooxygenases or prostaglandinendoperoxide synthase (PTGS) (55), the cytochrome P450 enzyme family (14), and nonheme lipoxygenases (21).

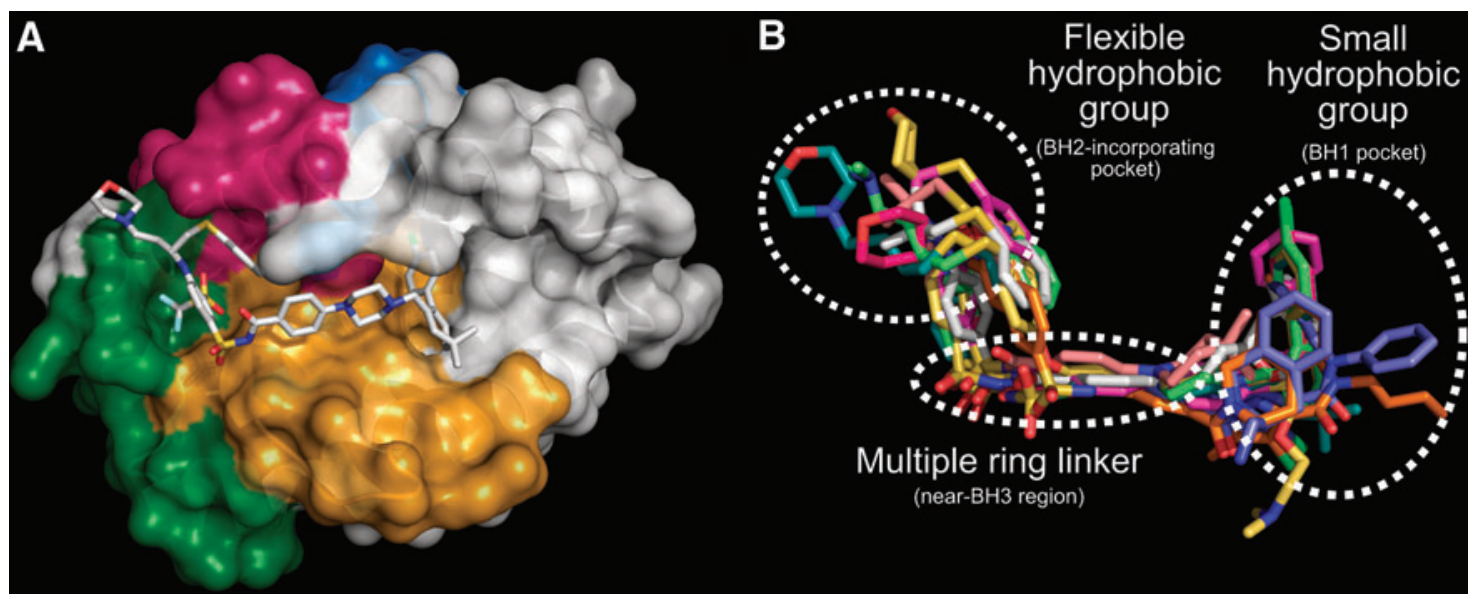

FIG. 6. Structural determinants of small molecule interactions with Bcl-2. (A) Bcl-2 in complex with navitoclax (ABT-263) (PDB 4LVT). (B) Overlay of all small molecules structurally characterized in complex with Bcl-2, highlighting key molecular features present in the majority of ligands. To see this illustration in color, the reader is referred to the web version of this article at www.liebertpub.com/ars 
ROS as signaling molecules. It is now widely accepted that ROS function as important signaling molecules, implicated in nuclear factor kappa-light-chain-enhancer of activated $\mathrm{B}$ cells $(\mathrm{NF}-\kappa \mathrm{B})$, mitogen-activated protein kinase (MAPK), Keap1-Nrf2-ARE, PI3K-Akt, Notch, and Wnt signaling pathways $(20,192)$. The various functional consequences of an altered redox milieu have been associated with a critical balance between the two major ROS molecules, $\mathrm{O}_{2}{ }^{-}$and $\mathrm{H}_{2} \mathrm{O}_{2}$ $(34,145,156)$. Whereas an overwhelming increase in either of these species results in cell injury and death, a tilt in the ratio in favor of $\mathrm{O}_{2}{ }^{--}$confers a survival advantage, while a significant shift toward $\mathrm{H}_{2} \mathrm{O}_{2}$ creates a permissive environment for death execution $(84,144)$. For example, $\mathrm{H}_{2} \mathrm{O}_{2}$ is known to suppress $\mathrm{Wnt} / \beta$-catenin signaling, an important survival and growth pathway, through a variety of mechanisms, including targeting the interaction between nucleoredoxin and disheveled (Dvl) (52) and via oxidative modification of the zinc-coordinating cysteines of tankyrase resulting in its inactivation (78). Interestingly, ROS-mediated Wnt signaling regulation of BCL2 involving GSK $3 \beta / \beta$-catenin has been reported on chronic exposure to $\mathrm{Cr}(\mathrm{VI})$ compounds (166). NF- $\kappa \mathrm{B}$ signaling is closely linked to the transcriptional regulation of Bcl-2(22). Furthermore, Nrf2-ARE signaling can also regulate BCL2 transcription through the antioxidant response elements (ARE) located within the $B C L 2$ promoter under conditions of oxidative stress (129). Interestingly, there is evidence of considerable cross talk between Nrf2 and NF- $\kappa$ B (181). For a more detailed account of the disparate functional outcomes on changes in intracellular ROS, please refer to these two comprehensive reviews $(153,154)$.

\section{The cross talk between cellular redox status and $\mathrm{Bcl}-2$}

Apart from the role of Bcl-2 as a major regulator of apoptosis and cell fate, there is convincing experimental evidence to indicate a close interplay between cellular redox status and Bcl-2 expression. Of note, there are reported observations supporting both a pro-oxidant activity and an antioxidant activity of Bcl-2 $(68,197)$. Not only does the expression of Bcl-2 impact intracellular redox milieu but also a reciprocal regulation of Bcl-2 expression and/or function has been associated with intracellular ROS (26). For example, Bcl-2 has been shown to modulate intracellular ROS through increased catalase and glutathione peroxidase/reductase expression (46), as well as increased total levels of NADPH and reduced glutathione (GSH) (47). On the flip side of it, there is emerging and significant evidence that Bcl-2 expression impacts mitochondrial ROS metabolism to stimulate $\mathrm{O}_{2} \cdot{ }^{-}$production, through increased $\mathrm{COX}$ activity, thereby creating a pro-oxidant environment that favors cell survival $(26,145)$.

The mRNA expression of BCL2 is also tightly correlated with the expression of genes involved in ROS detoxification and production (Fig. 7). Many peroxidase elimination enzymes, such as peroxiredoxins, and other redox proteins, such as thioredoxins, exhibit a strong negative correlation with $B C L 2$. This relationship may be due to an intrinsic mechanism through which cellular redox levels are in a constant pro-oxidant state, facilitating cancer cell survival. This prooxidant environment has been established as critical for the stability and antiapoptotic function of Bcl-2 (107). This hypothesis is also supported by a strong positive correlation between $\mathrm{O}_{2}{ }^{-}$producing enzymes NADPH oxidases, NOX2 and NOX4. Interesting to note is the strong negative correlation between $B C L 2$ and SOD1 across 18 of the 21 cancers surveyed, while SOD2 only exhibits a negative correlation in tumors with higher expression of BCL2. SOD3, the extracellular superoxide dismutase, was found to be positively correlated with Bcl-2 expression. The negative correlation of $B C L 2$ with $S O D 1$ in multiple cancers supports the notion that Bcl-2 may also function to maintain the pro-oxidant intracellular milieu necessary for cell survival (107). These data suggest that the expression of BCL2 is strongly correlated with the expression of many antioxidant enzymes and the tight interplay between regulating intracellular redox levels plays an important role in cell fate, especially in the context

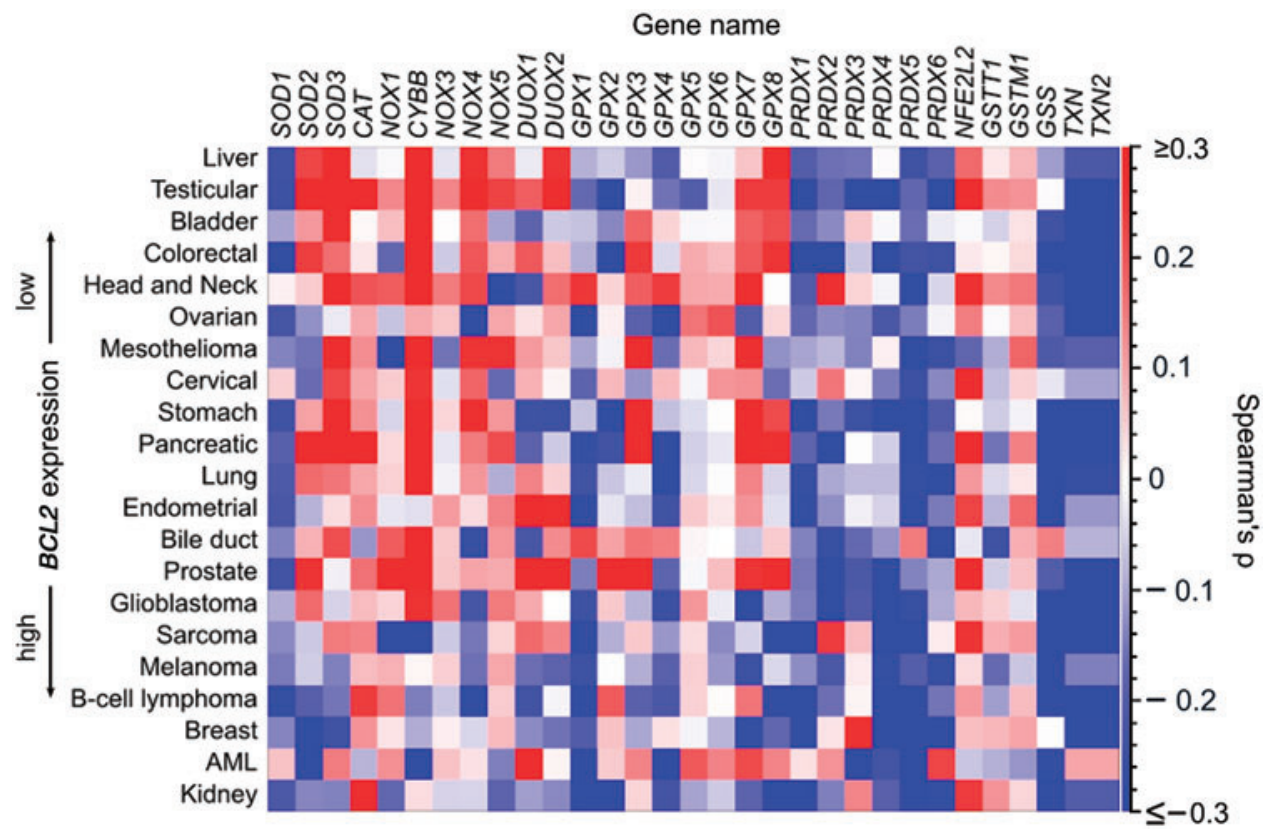

FIG. 7. Correlation between $B C L 2$ and antioxidant genes. Cancers were sorted from Bcl-2 high to low mean mRNA expression as obtained from TCGA data sets. Correlations (Spearman's $\rho$ ) are indicated as red-whiteblue gradient (positive-nonenegative). To see this illustration in color, the reader is referred to the web version of this article at www .liebertpub.com/ars 
of carcinogenesis. A list of key publications in terms of Bcl-2 and the regulation of Bcl-2 by ROS have been described in Table 2.

$\mathrm{Bcl}-2$ serves as a protector against oxidative insult. The protective role of Bcl-2 on an overt oxidative stress was originally discovered after Bcl-2-overexpressing cells demonstrated increased resistance to $\mathrm{H}_{2} \mathrm{O}_{2}$ and menadioneinduced cell death (68). Subsequently, contradicting evidence has emerged to suggest that Bcl-2-mediated cellular protection from $\mathrm{H}_{2} \mathrm{O}_{2}$ was both independent (3) and dependent (73) on NF- $\kappa$ B activation. The latter study indicated that Bcl-2 induces constitutively active NF- $\kappa \mathrm{B}$ signaling, resulting in the upregulation of $\gamma$-glutamylcysteine ligase, the first enzyme in the biosynthetic pathway of GSH (73). Transcriptional regulation of $B C L 2$ by NF- $\kappa \mathrm{B}$ is now well characterized $(22,63)$. Bcl-2 is able to provide protection against other oxidizing species, including potassium cyanide, tertbutyl hydroperoxide (165), and $\gamma$-irradiation $(122,196)$.

The protective role of $\mathrm{Bcl}-2$ also includes safeguarding against nitric oxide (NO)-induced apoptosis (116). Bcl-2overexpressing murine macrophages exposed to $\mathrm{NO}$ donors, $S$-nitrosoglutathione (GSNO) and spermine-NO, and activators of inducible NO, lipopolysaccharide and interferon- $\gamma$, demonstrated apoptotic resistance to that of their neo control cells (116). While it has often been hypothesized that the mechanism by which Bcl-2 protects against oxidative insult is an intrinsic antioxidant property $(68,69,95,157)$, current evidence suggests that the antioxidant activity of Bcl-2 is merely a secondary effect $(36,54)$. Bcl-2 may be thought of as an "antioxidant-by-proxy" when in complex with GSH (197); this is discussed in detail in the following section (Mitochondrial-Dependent Regulation of Cellular Redox by Bcl-2). Cox and Hampton (36) demonstrated that Bcl-2 was able to protect cells against apoptotic $(<200 \mu M)$, but not necrotic $(>200 \mu M)$, doses of $\mathrm{H}_{2} \mathrm{O}_{2}$. These cells also showed no difference in the levels of GAPDH and peroxiredoxin 2 oxidation, while exhibiting evidence of increased micronuclei formation and genomic instability. This suggests that the antiapoptotic and pro-oncogenic role of Bcl-2 is through preventing the elimination of cells damaged by oxidation (36). Besides the apparent antioxidant activity of Bcl-2, recent evidence also suggests that $\mathrm{Bcl}-2$ promotes cell survival by providing a pro-oxidant environment capable of supporting tumorigenesis $(26,170,189)$.

Mitochondrial-dependent regulation of cellular redox by $\mathrm{Bcl}-2$. Mitochondrial metabolism and its redox environment are highly dependent on Bcl-2 and GSH (111). In this respect, Bcl-2 regulates the mitochondrial pool of GSH and may act as a redox sensor. GSH may be displaced from Bcl-2 via competitive binding of BH3-only proteins (e.g., Bim) and BH3 mimetics (e.g., ABT-737) and induces mitochondrial dysfunction, oxidative stress, and cell death (197). Recently, it was demonstrated that Bcl-2 and 2-oxoglutarate carrier (OGC), a glutathione transport molecule, directly interact in the presence of GSH. This suggests that $\mathrm{Bcl}-2$ and OGC participate in the transport of GSH to increase the glutathione

Table 2. List of Milestone Publications for Bcl-2 and Its Interplay with Reactive Oxygen Species

Key publications in the interplay between Bcl-2 and ROS

\begin{tabular}{|c|c|c|c|}
\hline Authors & Year & Journal & Publications \\
\hline Tsujimoto et al. (175) & 1984 & Science & $\begin{array}{l}\text { Cloning of the chromosome breakpoint of neoplastic } \\
\text { B cells with the } t(14 ; 18) \text { chromosome translocation }\end{array}$ \\
\hline Hockenbery et al. (67) & 1990 & Nature & $\begin{array}{l}\text { Bcl-2 is an inner mitochondrial membrane protein that } \\
\text { blocks programmed cell death }\end{array}$ \\
\hline Hockenbery et al. (68) & 1993 & Cell & Bcl-2 functions in an antioxidant pathway to prevent apoptosis \\
\hline Oltvai et al. (135) & 1993 & Cell & $\begin{array}{l}\text { Bcl-2 heterodimerizes in vivo with a conserved homolog, } \\
\text { Bax, that accelerates programmed cell death }\end{array}$ \\
\hline Yin et al. (191) & 1994 & Nature & $\begin{array}{l}\mathrm{BH} 1 \text { and } \mathrm{BH} 2 \text { domains of Bcl- } 2 \text { are required for inhibition } \\
\text { of apoptosis and heterodimerization with } \mathrm{Bax}\end{array}$ \\
\hline Muchmore et al. (119) & 1996 & Nature & $\begin{array}{l}\text { X-ray and NMR structure of human Bcl-xL, an inhibitor } \\
\text { of programmed cell death }\end{array}$ \\
\hline Petros et al. (146) & 2001 & PNAS & Solution structure of the antiapoptotic protein bcl-2 \\
\hline HIldeman et al. (66) & 2003 & PNAS & Control of Bcl-2 expression by reactive oxygen species \\
\hline Clement et al. (33) & 2003 & $\begin{array}{l}\text { Cell Death and } \\
\text { Differentiation }\end{array}$ & $\begin{array}{l}\text { Decrease in intracellular superoxide sensitizes Bcl-2- } \\
\text { overexpressing tumor cells to receptor and drug-induced } \\
\text { apoptosis independent of the mitochondria }\end{array}$ \\
\hline Oltersdorf et al. (134) & 2005 & Nature & $\begin{array}{l}\text { An inhibitor of Bcl-2 family proteins induces regression } \\
\text { of solid tumours }\end{array}$ \\
\hline Cox and Hampton (36) & 2007 & Carcinogenesis & $\begin{array}{l}\text { Bcl- } 2 \text { over-expression promotes genomic instability by } \\
\text { inhibiting apoptosis of cells exposed to hydrogen peroxide }\end{array}$ \\
\hline Chen and Pervaiz (26) & 2007 & $\begin{array}{l}\text { Cell Death and } \\
\text { Differentiation }\end{array}$ & $\begin{array}{l}\text { Bcl- } 2 \text { induces pro-oxidant state by engaging mitochondrial } \\
\text { respiration in tumor cells }\end{array}$ \\
\hline Chen and Pervaiz (27) & 2010 & $\begin{array}{l}\text { Cell Death and } \\
\text { Differentiation }\end{array}$ & $\begin{array}{l}\text { Involvement of cytochrome c oxidase subunits } \mathrm{Va} \text { and } \mathrm{Vb} \\
\text { in the regulation of cancer cell metabolism by Bcl-2 }\end{array}$ \\
\hline Velaithan et al. (178) & 2011 & Blood & $\begin{array}{l}\text { The small GTPase Rac1 is a novel binding partner of Bcl-2 } \\
\text { and stabilizes its antiapoptotic activity }\end{array}$ \\
\hline Low et al. (107) & 2014 & Blood & $\begin{array}{l}\text { Ser70 phosphorylation of } \mathrm{Bcl}-2 \text { by selective tyrosine nitration } \\
\text { of PP2A-B56delta stabilizes its antiapoptotic activity }\end{array}$ \\
\hline
\end{tabular}


mitochondrial pool, and a mechanism through which the mitochondria are protected from oxidative stress (184). It has been shown that Bcl-2 overexpression relocalized GSH to the nucleus, altering nuclear redox and blocking caspase activation to promote cell survival (179). Glutathione homeostasis regulated by $\mathrm{Bcl}-2$ has been shown in MCF-7 breast cancer cells, where Bcl-2 overexpression increases glutathione content, although this was found to be independent of changes in gene expression related to glutathione synthesis. The inhibition of glutathione synthesis was able to overcome Bcl-2-induced cisplatin resistance (160).

The mechanisms by which Bcl-2 regulates mitochondrial respiration are vital for the understanding and interpretation of the overall cellular redox environment (106). Bcl-2 expression has been linked to the activity of cytochrome $c$ oxidase $(\mathrm{COX})$, the rate-limiting enzyme in mitochondrial electron transport chain (ETC), and thus vital in the regulation of mitochondrial respiration (26). Leukemic lymphoblastic cells (CEM cell line) overexpressing Bcl-2 exhibited higher levels of mitochondrial $\mathrm{O}_{2}^{-{ }^{-}}$, oxygen consumption, and higher COX activity, while the opposite was seen after the introduction of siRNA directed at $B C L 2(26,27)$. It should be pointed out that the effect of Bcl-2 on mitochondrial COX activity and oxygen consumption is dependent on the redox milieu of the mitochondria. In this regard, under states of normoxia, Bcl-2 upregulates mitochondrial respiration and $\mathrm{COX}$ activity through increased import and assembly of COX subunits $\mathrm{Va}$ and $\mathrm{Vb}$ (27).

Evidence also suggests a possible interaction between $\mathrm{Bcl}-2$ and $\mathrm{COX} \mathrm{Va}$, and higher expression of $\mathrm{Bcl}-2$ promoted the mitochondrial translocation of COX Va. On the contrary, during states of overt oxidative stress induced on pharmacologically inhibition of mitochondrial ETC complexes, Bcl-2 overexpression elicited a negative effect on mitochondrial respiration and COX activity. The latter is corroborated by a recent report demonstrating that conditional $B C L 2$ knockout in murine pancreatic $\beta$ cells exhibited increased superoxide dismutase (SOD) activity, increased mitochondrial respiration, and ultimately, cell death (2). The regulatory effect of Bcl-2 on mitochondrial respiration has also been reported in neuronal cells (77), in SOD $1^{\mathrm{G} 93 \mathrm{~A}}$ mouse models of amyotrophic lateral sclerosis (138), rat ascites hepatoma (165), and hepatocytes (176).

$\mathrm{Bcl}-2$-dependent increase in mitochondrial $\mathrm{O}_{2}{ }^{-}$levels was also associated with the downstream activation of signal transducer and activator of transcription 3 (STAT3), which was mediated through a function of Rac1 (79). Overexpression of Bcl-2 induced phosphorylation of STAT3 on Tyr705, which was mediated by increased $\mathrm{O}_{2}{ }^{--}$. Furthermore, constitutively active mutants of STAT3 increased mitochondrial $\mathrm{O}_{2} \cdot-$ production (79). This study demonstrates the numerous signaling pathways that Bcl-2 can influence in regulating mitochondrial redox metabolism.

Bcl-2 family members have also been shown to mediate the switch between mitochondrial fusion and fission, which in turn suggests an influence of the family on mitochondrial metabolism and bioenergetics (183). Mammalian proteins Drp-1 and Fis-1 have been shown to be crucial in mitochondrial fission, while Mfn1/2 and OPA1 have been shown to play a role in fusion events. Bcl-2 family members Bax and Bak are required for mitochondrial fusion, where Bax interacts directly with Mfn2 (80). Bax has also been shown to colocalize with both Drp1 and Mfn2 during apoptosis and promotes mitochondrial fragmentation (164). Mammalian Bcl-2 is yet to be identified in having a role in either profusion or fission events (159), although it has also been described in the Caenorhabditis elegans homologue CED-9 (108). The study by Lu et al. found that CED-9 interacts with DRP-1 to promote mitochondrial fission. One could then speculate that Bcl-2 may function as a receptor for DRP-1 in a mammalian system to promote changes in mitochondrial dynamics and metabolism, although this is yet to be proven (159).

Taken together, it appears that the regulation of mitochondrial ROS extends into a variety of cellular contexts, and therefore, an alternative therapeutic strategy against refractory cancers could be to target key players involved in the regulation of mitochondrial metabolism to favorably modulate the cellular redox milieu for death execution (142).

Oxidative stress induced transcriptional regulation of $B C L 2$. Early studies assessing the relationship between oxidative stress and BCL2 expression indicated that acute oxidative stress induced by bright light in retinal rod receptor cells and cyclosporin A in human endothelial cells reduced BCL2 expression (104). Later studies in $\mathrm{t}(14 ; 18)$ lymphoma cells revealed that $B C L 2$ expression is tightly linked to $\mathrm{NF}-\kappa \mathrm{B}$ activation by the presence of cyclic AMP response element (CRE) and Sp1 binding sites (63). In prostate cancer cells, the overexpression of p50/p65 subunits of NF- $\kappa$ B increased expression of $B C L 2$, and likewise, stimulation with TNF- $\alpha$ resulted in an increase in $B C L 2$ promoter activity (22). In U937 cells, NF- $\kappa \mathrm{B}$ has also been implicated in ROS-induced upregulation of $B C L 2$ (37). BCL2 transcriptional regulation has also been linked to Sonic hedgehog signaling through gli-1 and $\mathrm{Wnt} / \beta$-catenin signaling by Wnt3a stimulation in osteoblast progenitor cells (5).

ROS have been shown to regulate $B C L 2$ gene expression indirectly, through which variations in cellular ROS levels lead to both an increase or decrease in BCL2 gene expression depending on the cell context. Hildeman et al. (66) demonstrated that the addition of antioxidant manganese (III) tetrakis (4-benzoic acid)porphyrin (MnTBAP) to T cells in vivo significantly increased $B C L 2$ gene expression, although did not regulate other Bcl-2 family members, including $\mathrm{Bcl}-\mathrm{xL}$, Bad, and BimEL. MnTBAP also decreased intracellular ROS levels and inhibited death execution. ROS production was shown to be upstream of BCL2 downregulation and to involve a Bim-independent mechanism. These results were mirrored by retroviral expression of catalase, which increased BCL2 expression and rescued cells from oxidative stress-induced cell death (66). Similarly, $\mathrm{H}_{2} \mathrm{O}_{2}$ induced downregulation of $\mathrm{Bcl}-2$ protein and gene expression, while concurrently upregulating Bax in cardiac myocytes (113). While the majority of studies have found that BCL2 was downregulated when exposed to oxidative stress, Kaufmann et al. found that aged rats had increased BCL2 expression in the hippocampus and cerebellum, which was a consequence of oxidative stress (81).

Bcl-2 regulation through oxidative stress was also demonstrated in hippocampal neurons, where the addition of $\mathrm{H}_{2} \mathrm{O}_{2}$ and glucose oxidase resulted in a decrease in BCL2 gene and protein expression (150). The downregulation of Bcl-2 and concurrent increase in oxidative stress-induced apoptosis were able to be rescued through the addition of $N$-acetylcysteine (NAC), which subsequently increased Bcl-2 expression (151). 
Transcriptional regulation of $B C L 2$ is partly controlled by cyclic AMP response element binding protein (CREB) (185). Oxidative insult through $\mathrm{H}_{2} \mathrm{O}_{2}$ or glucose oxidase decreased CREB activity on the $B C L 2$ promoter, which was reversed in the presence of NAC and manganese (III) tetrakis (1-methyl4-pyridyl) porphyrin (MnTMPyP) (150). In rat liver, the induction of oxidative stress with triiodothyronine (T3) resulted in increased Bcl-2 expression, which was abrogated with the addition of $\alpha$-tocopherol (vitamin E) (48). These studies demonstrate that Bcl-2 not only regulates the cellular redox milieu but oxidative stress itself can reciprocally regulate Bcl-2 expression as well.

Posttranslational modifications of $\mathrm{Bcl}-2$ mediated by oxidative stress. The regulation of apoptosis by $\mathrm{Bcl}-2$ has been shown to be mediated through various kinases, ligands, and oxidative stress signals due to changes in the expression and function of antioxidant enzymes. The regulation of Bcl-2 by posttranslational modification induced by oxidative stress is summarized in Figure 8. Bcl-2 suppression of apoptosis is partly facilitated through its direct interaction with extracellular signal-related kinase (ERK) 1/2 (109). This interaction can be regulated through oxidative stress, through which increased $\mathrm{H}_{2} \mathrm{O}_{2}$ induces $\mathrm{Bcl}-2$ cysteine oxidation and the disruption of the ERK1/2-Bcl-2 complex. Mutagenesis indicated that the key residues regulating this interaction were
Cys158 and Cys229. Cys158 is located adjacent to the Bcl-2 BH1 domain and is buried in both the monomeric and putative dimer forms (Fig. 2C) of the protein, although may become exposed during the conformational change that would be required to achieve dimer formation; Cys229 is suggested to be located within the Bcl-2 transmembrane helix. A C158A and C229A double mutant was resistant to oxidation, as well as $\mathrm{H}_{2} \mathrm{O}_{2}$-induced ubiquitination and subsequent degradation (109). The degradation of Bcl-2 through the ubiquitin-mediated pathway is also regulated by $\mathrm{TNF}-\alpha$ induced oxidative stress. $\mathrm{H}_{2} \mathrm{O}_{2}$ and TNF- $\alpha$-induced oxidative stress resulted in degradation of $\mathrm{Bcl}-2$, which was linked to the dephosphorylation of Ser87. The resultant dephosphorylation after TNF- $\alpha$ stimulation was demonstrated to be protein phosphatase 2 (PP2A) and PP2B independent (16). $\mathrm{H}_{2} \mathrm{O}_{2}$ has also been shown to regulate PKC-mediated $\mathrm{Bcl}-2$ phosphorylation through a phospholipase $\mathrm{C} \gamma 1$-dependent (PLC- $\gamma 1$ ) mechanism. Plcg1 null cells exhibited reduced viability and reduced $\mathrm{Bcl}-2$ phosphorylation, following an insult with low levels of $\mathrm{H}_{2} \mathrm{O}_{2}$ (10).

Furthermore, c-Jun N-terminal kinase (JNK) activation can induce apoptosis through phosphorylation and inactivation of Bcl-2 (188). In response to menadione-induced oxidative stress, JNK phosphorylation and degradation of Bcl-2 were increased, but could be blocked on addition of NAC (193). Contrary to this study, Kelkel et al. demonstrated

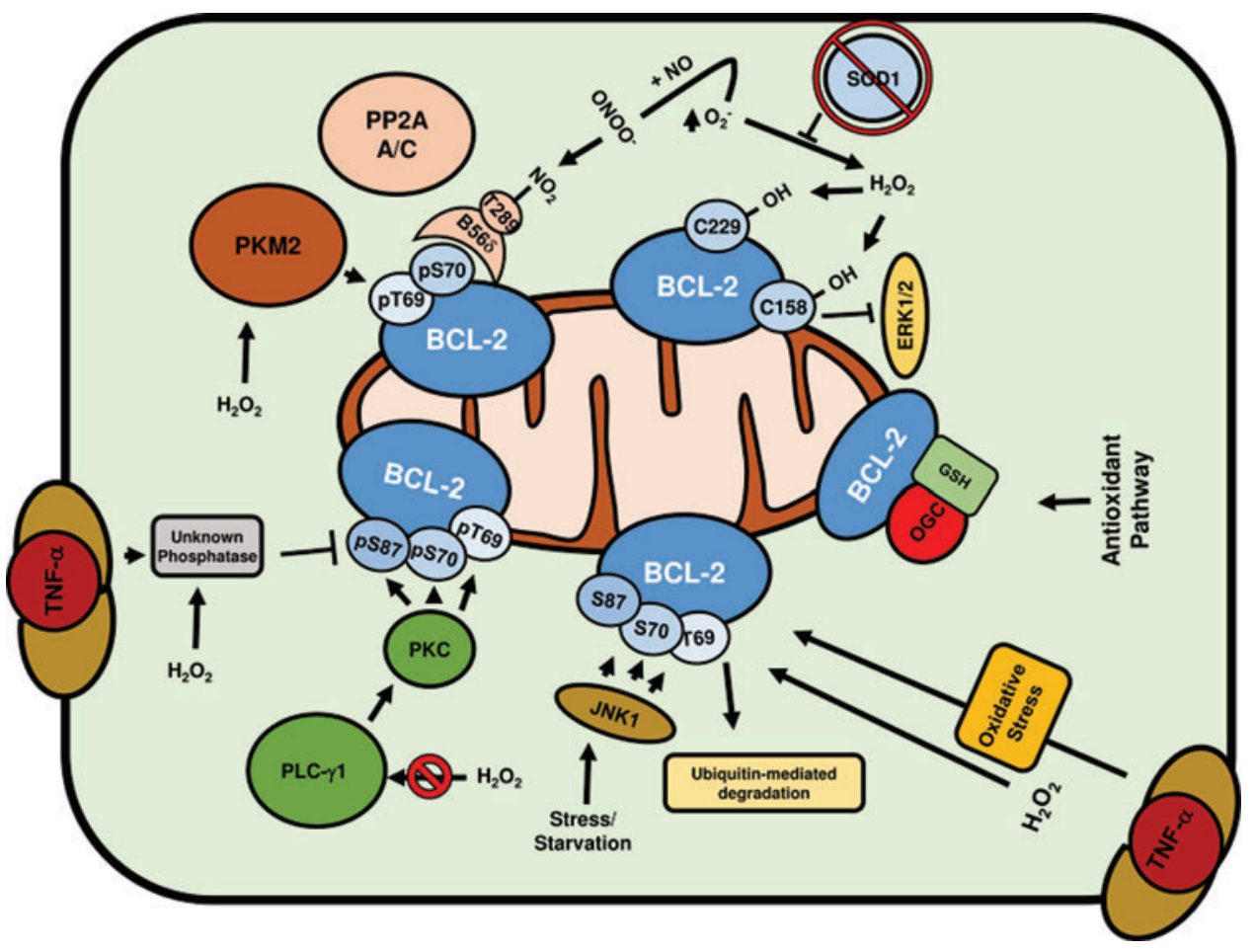

FIG. 8. Schematic of post-translational modifications of Bcl-2 due to oxidative stress. Posttranslational modifications of Bcl-2 occur under an insult of oxidative stress. Depletion or inhibition of SOD1 can initiate nitration of T289 on PP2A's B56 $\delta$ subunit, preventing binding to the $\mathrm{A} / \mathrm{C}$ subunits and the generation of the holo-enzyme. This prevents dephosphorylation of Ser70 of Bcl-2, stabilizing its antiapoptotic ability. Hydrogen peroxide can stabilize Bcl-2 through PKM2-mediated phosphorylation of T69, as well as causing its degradation through the ubiquitin-mediated pathway. PLC- $\gamma 1$ mediates hydrogen peroxide resistance allowing phosphorylation of key residues by PKC and stabilization, while the opposite can also occur where hydrogen peroxide can stimulate dephosphorylation of Bcl-2. During cellular stress and starvation, JNK1 has also been shown to phosphorylate Bcl-2 at T69/S70/ S87. Bcl-2 interacts with GSH and OGC to regulate the mitochondrial pool of GSH. GSH, glutathione; $\mathrm{H}_{2} \mathrm{O}_{2}$, hydrogen peroxide; $\mathrm{NO}$, nitric oxide; $\mathrm{ONOO}^{-}$, peroxinitrite; OGC, 2-oxoglutarate carrier; PLC- $\gamma 1$, phospholipase Cc1-dependent; PPA2, protein phosphatase 2. To see this illustration in color, the reader is referred to the web version of this article at www.liebertpub.com/ars 
that JNK activation and phosphorylation of Bcl-2 were independent, via the addition of the ROS-inducing agent diallyl tetrasulfide to U937 human histiocytic lymphoma cells (82). These opposing results suggest that redox-dependent posttranslational modifications of $\mathrm{Bcl}-2$ are highly dependent on the level of ROS. High levels of $\mathrm{H}_{2} \mathrm{O}_{2}$ primarily result in oxidation of Bcl-2 and degradation, while low levels initiate phosphorylation and stabilization of Bcl-2.

Functionally, ROS-mediated Bcl-2 phosphorylation has been linked to cell cycle transitions (39). The expression of phosphomimetic, gain-of-function Bcl-2 mutants (S70E and $\mathrm{T} 69 \mathrm{E} / \mathrm{S} 70 \mathrm{E} / \mathrm{S} 87 \mathrm{E}$ ) reduced intracellular ROS and inhibited G1/S cell cycle progression. The reduced G1/S phase progression was overridden by the addition of $\mathrm{H}_{2} \mathrm{O}_{2}$, through the downregulation of p27 and increased activation of $\mathrm{Cdk} 2$. Decreased ROS were attributed to increased SOD1 and catalase expression, which resulted in an antioxidant intracellular milieu on expression of the Bcl-2 phosphomimetics (39).

The relationship between the members of the SOD family and $\mathrm{Bcl}-2$ has been explored in a number of cellular contexts. In spinal cord mitochondria, mutant SOD1 (G93A) and wildtype $\mathrm{Bcl}-2$ have been shown to interact in the mitochondria, where they promote structural abnormalities and mitochondrial dysfunction. The mutant SOD1 causes a conformational change in Bcl-2, resulting in the exposure of the $\mathrm{BH} 3$ domain, which promotes mitochondrial toxicity (140). Low et al. (107) demonstrated that the stability and antiapoptotic function of Bcl-2 were enhanced in a pro-oxidant environment. Specifically, reducing SOD1 activity either by pharmacological means or siRNA directed at SOD1 increased phosphorylation of Bcl-2 at Ser70 (pSer70). Increased levels of $\mathrm{ONOO}^{-}$, as a result of increased $\mathrm{O}_{2}{ }^{-}$, induced selective nitration of Tyr289 of the B56 $\delta$ subunit of PP2A. ONOO ${ }^{-}$induced nitration of PP2A at Tyr289 prevented the assembly of the holoenzyme involving the regulatory $\mathrm{B}$ subunit and the core A-C subunits. Importantly, SOD1 expression and Bcl-2 pSer70 were found to be negatively correlated in vivo; high Bcl-2 p70 could predict a poor patient prognosis. Furthermore, in vitro studies showed an association between high levels of Bcl-2 pSer70 and chemoresistance. This suggests the possibility for the use of redox modulators as chemosensitizers in the treatment of lymphomas (107). The study by Low et al. provided mechanistic insight to observations published previously by Zhao et al., demonstrating that Bcl-2 pSer70 was required for protection against oxidative stress, which was abolished through the activation of PP2A (194).

Liang et al. (100) recently demonstrated that under $\mathrm{H}_{2} \mathrm{O}_{2}$ induced oxidative stress, Bcl-2 is stabilized through phosphorylation of Thr69 (pThr69) by pyruvate kinase M2 isoform (PKM2), promoting tumorigenesis in glioma cells. Oxidative stress induces mitochondrial translocation and a potential conformational change in PKM2, resulting in the phosphorylation of Bcl-2 at Thr69. This potential conformational change may be facilitated through the ATPase activity of HSP90 $\alpha 1$ and permits the binding of PKM2 to Bcl-2. pThr69 prevents ubiquitination by a Cul3-based ubiquitin E3 ligase, thus preventing its degradation. This HSP $90 \alpha 1-$ PKM2-Bcl-2 axis is crucial in stabilizing the antiapoptotic function of Bcl-2 and driving tumorigenesis (100).

The Bcl-2:Beclin1 interaction has been demonstrated to be potentially redox dependent. Bcl-2/adenovirus E1B 19-kDa protein-interacting protein 3 (BNIP3) is a proapoptotic pro- tein, whose expression is regulated by HIF-1 $\alpha$. It functions as a redox sensor during times of prolonged hypoxia-induced oxidative stress. Dimerization of BNIP3 was shown to be sensitive to $\mathrm{H}_{2} \mathrm{O}_{2}$-induced oxidative stress (87). Hypoxiainduced BNIP3 expression has been demonstrated to disrupt the interaction between Bcl-2 and Beclin 1 to induce autophagy (12). These studies show that apoptosis and autophagy are clearly linked to specific Bcl-2 binding partners in various cellular components. To that end, $S$-nitrosylation of Bcl-2 negatively regulates autophagy; nitrosylation of Cys 158 and Cys229 stabilizes the interaction between Bcl-2 and Beclin1, thereby inhibiting Beclin1 activity and as a result decreasing autophagic flux (187). This effect is reversed on addition of ABT-737, aminoguanidine (NO inhibitor), and a redoxinactive Bcl-2 double-mutant (C158A/C299A). Interestingly, these cysteine residues were previously shown to be prone to $\mathrm{H}_{2} \mathrm{O}_{2}$-induced oxidation (109).

Furthermore, $S$-nitrosylation of Bcl-2 was previously demonstrated to inhibit its ubiquitin-mediated proteasomal degradation. This NO-mediated effect was independent of Ser87 phosphorylation and decreased cellular apoptosis (9). These studies highlight the importance of NO-driven signaling and Bcl-2 in the regulation of autophagic and apoptotic signaling. NO has also been demonstrated to increase carbonylation of Bcl-2 (19), and IL- $1 \beta$-induced NO production increased Bcl-2 carbonylation, which preceded its downregulation. The downregulation of $\mathrm{Bcl}-2$ coincided with an increase in NO-mediated DNA fragmentation (19). This is contrary to the previously mentioned studies where NO was associated with resistance to apoptosis, suggesting that the regulation of cell fate by NO is dependent on the precise posttranslational modification of Bcl-2.

$\mathrm{Bcl}-2$ and peroxide eliminating enzymes. A study by Gouaze et al. (58) demonstrated that glutathione peroxidase-1 (GPx1) overexpressing cells were resistant to CD95-induced apoptosis. T47D cells overexpressing GPx1 exhibited lower levels of ROS and Bcl-2. Similarly, Clement et al. (33) showed that Bcl-2 overexpression blocked CD95-induced cell death, which was restored on NOX inhibition or overexpression of dominant-negative Rac1, decreasing overall levels of $\mathrm{O}_{2}{ }^{--}$. To that end, Rac1 has also been demonstrated to increase $\mathrm{O}_{2}{ }^{-}$and inhibit apoptosis in melanoma and bladder carcinoma cells (143). Further studies provided evidence for an interaction between Bcl-2 and Rac1 in leukemic cells that increased intracellular $\mathrm{O}_{2}{ }^{-}$, thus creating a prooxidant environment that favors cell survival and/or inhibits apoptotic execution (178). Synthetic BH3 peptides and BH3 mimetics were able to block the interaction of Rac1 and Bcl2 , decrease $\mathrm{O}_{2}{ }^{--}$production, and sensitize human leukemia cells to chemotherapeutics. Previously, it was also demonstrated that Rac1 was needed for the phosphorylation of Bcl-2 by the JNK/stress-activated protein kinase $(\mathrm{JNK} / \mathrm{SAPK} \beta$ ) p54-SAPK $\beta$ (114).

Peroxiredoxins are functional antioxidant enzymes that control intracellular peroxide levels. BCL2 mRNA expression has been shown to exhibit a primarily negative correlation with the five peroxiredoxins (PRDX1, PRDX3, PRDX4, $P R D X 5$, and $P R D X 6)$ in a wide range of primary tumor samples. In lung cancer either a weak or negative correlation is observed (Fig. 7). In A549 lung cancer cells with gefitinib resistance (A549/GR), shRNA knockdown of $P R D X 2$ resulted 
in a decrease in $\mathrm{Bcl}-2$ expression and concurrent increase in peroxide levels in the cell, culminating in cell death (89). The change in correlation in gefitinib-resistant cells can be hypothesized to be directly due to JNK/ROS activation, both of which were altered compared to the A549 cells. $\mathrm{H}_{2} \mathrm{O}_{2}$ also protected cardiomyocytes from oxidative stress-induced apoptosis, which was associated with an increase in $\mathrm{Bcl}-2 . \mathrm{H}_{2} \mathrm{O}_{2-}$ induced oxidative stress caused a decrease in the level of both Prx 2 and Bcl-2, showing a strong correlation between intracellular peroxide levels and Bcl-2 expression (195). Bcl-2 expression has also been shown to be associated with members of the thioredoxin family. The use of antisense BCL2 therapy in neuroblastoma cells demonstrated that decreasing levels of Bcl-2 were associated with increasing levels of thioredoxin. This seems to be consistent across a range of tumors (Fig. 7) and may involve a cellular compensatory mechanism when cells are undergoing oxidative stress (99).

Redox-dependent regulation of $\mathrm{Bcl}-2$ in viral infection. Intracellular regulation of cellular redox has been shown to be an important factor in viral establishment, replication, and progression (11). A pro-oxidant environment has been demonstrated during infection with influenza (64), human immunodeficiency virus (HIV) (65), and hepatitis C (57). Bcl-2 has been demonstrated to influence cellular redox and alter viral replication in various settings. During influenza A replication, cellular levels of GSH are decreased, resulting in a pro-oxidant environment. Cells overexpressing Bcl-2 exhibited higher levels of GSH and produced less virus (126). Influenza A infection has also been shown to increase ROS in an NOX-4-dependent manner (6). Mechanistically, viral activation in $\mathrm{Bcl}-2^{+}$cells induced p38MAPK-mediated phosphorylation of Bcl-2 at Thr56 and Ser87, resulting in cell death. siRNA-mediated knockdown of $B C L 2$ resulted in increased influenza A replication and viral ribonucleoprotein (vRNP) export (125). In asymptomatic HIV-infected patients, $\mathrm{H}_{2} \mathrm{O}_{2}$ production was increased in monocytes with parallel downregulation in thioredoxin and Bcl-2. These reductions were suggested to be a result of significantly increased oxidative stress (45). These studies highlight the importance of redox regulation in altering Bcl-2-mediated cell fate in viral infections. The role of Bcl-2 in viral infections and its interaction with viral proteins is comprehensively reviewed by Alibek et al. (4) Redox in viral infections have previously been reviewed elsewhere $(101,123,168)$.

\section{A brief overview of Bcl-2 inhibitors: past, present, and future}

As the discovery and development of Bcl-2 inhibitors have been recently comprehensively reviewed $(8,98)$, this section focuses primarily on molecules that have been or are currently under investigation through clinical trials (Fig. 9).

Oblimersen is an antisense oligonucleotide targeted to the $B C L 2$ mRNA, thus preventing Bcl-2 protein expression (41). It was the first molecule against $\mathrm{Bcl}-2$ to be investigated clinically. Oblimersen has been extensively investigated in clinical trials in a wide variety of solid tumors and blood cancers, and in combination with a wide variety of cancer therapeutics, however, its use as a single agent or in combination have not been approved for any clinical indication (51). The related molecule SPC2996 has also been investigated in clinical trials, which failed to demonstrate effective downregulation of $\mathrm{Bcl}-2$ expression (42). Oblimersen was demonstrated in PC3 cells to increase the oxidation of nuclear DNA, measured by 8-hydroxy-2'-deoxyguanosine staining,
FIG. 9. 2D structures of small molecule Bcl-2 inhibitors. (A) ABT-737. (B) Navitoclax (ABT-263). (C) Venetoclax (ABT-199). (D) Obatoclax. (E) Representative molecule from the patent describing the production of S55746-related molecules. (F) (-)-Gossypol (AT-101).

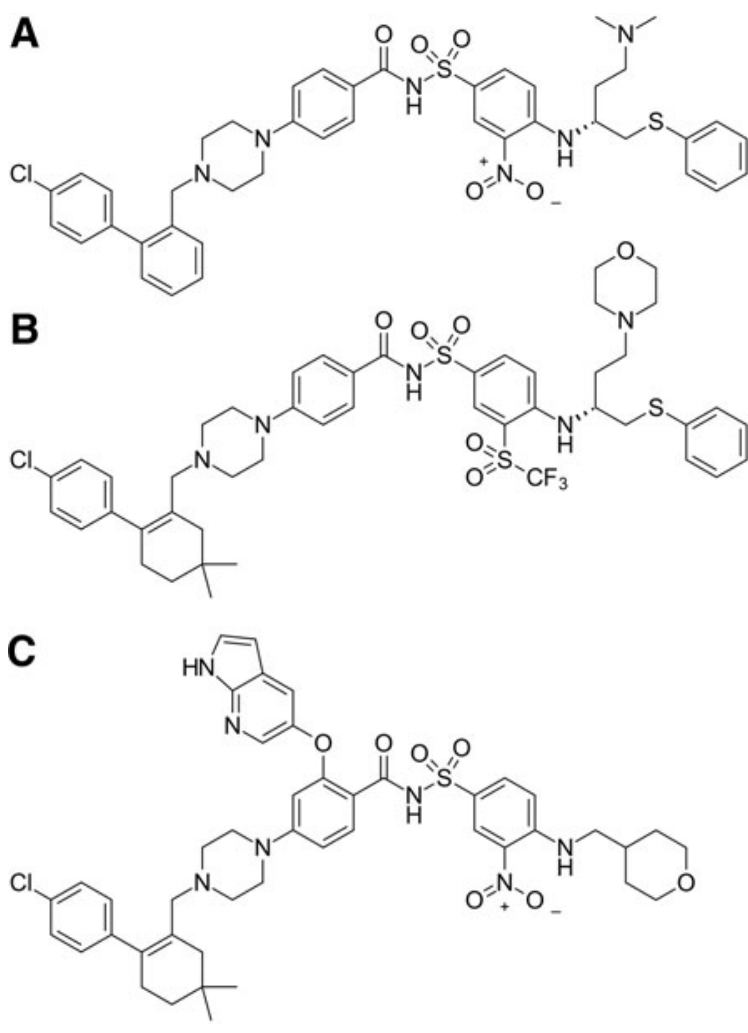<smiles>COC1=CC(c2cc3ccccc3[nH]2)=N/C1=C\c1[nH]c(C)cc1C</smiles><smiles>Cc1c(N(C(=O)c2cn(-c3cc4c(cc3C(=O)N3Cc5ccccc5C[C@H]3CN3CCOCC3)OCO4)c(C)c2-c2cc(F)c(C#N)n2C)c2ccc(O)cc2)c(C)n(C)c1C</smiles><smiles>Cc1cc2c(C(C)C)c(O)c(O)c(C=O)c2c(O)c1-c1cc(O)c2c(C=O)c(O)c(O)c(C(C)C)c2c1C</smiles> 
suggesting that cell death was due to an ROS-dependent mechanism (90).

ABT-737, which is generally regarded as the prototypical small molecule Bcl-2 family protein inhibitor, was first reported in 2005 (134). ABT-737 was discovered through a SAR by NMR (structure-activity relationship by nuclear magnetic resonance) approach, through which small organic "fragment" molecules (<200 Da) were assessed for weak/ moderate binding to Bcl-2 via NMR approaches (primarily saturation transfer difference spectroscopy and heteronuclear single quantum coherence spectroscopy), and subsequently "assembled" to generate molecules capable of tightly binding to Bcl-2. ABT-737 targets the hydrophobic peptidebinding groove of Bcl-family proteins nonselectively. The lack of oral bioavailability of ABT-737 has limited its clinical development, instead prompting the development of alternatives. Hepatocellular carcinoma (HCC) cells with high Bcl-2 expression demonstrated resistance to ABT-737 by suppressing the ROS-JNK pathway. In HCC cells expressing low levels of Bcl-2, apoptosis was induced after treatment with ABT-737 through increased ROS levels and activation of the ROS-JNK pathway (128). This study demonstrates that high levels of Bcl-2 can determine the effectiveness of ABT737 in a ROS-dependent mechanism.

Navitoclax (ABT-263) is an orally bioavailable analog of ABT-737 that has progressed to Phase II clinical trials. Navitoclax features three modifications relative to ABT-737: (i) replacement of the nitro group with a triflyl group; (ii) replacement of the dimethylamine with a morpholine group; and (iii) replacement of the 4-chlorobiphenyl group with a 1-(4-chlorophenyl)-4,4-dimethyl-cyclohexene group (137). These modifications enhance oral bioavailability relative to ABT-737, while maintaining protein binding and cellular efficacy. Navitoclax elicits thrombocytopenia as a result of Bcl-xL inhibition $(32,158,186)$, which limits its tolerated dose and has delayed its clinical development; nonetheless, trials involving navitoclax or combinations thereof are ongoing, largely against blood cancers.

Venetoclax (ABT-199, GDC-0199) is a Bcl-2-selective inhibitor derived from navitoclax, currently approved for the treatment of chronic lymphocytic leukemia. Venetoclax features three modifications relative to navitoclax: (i) replacement of the triflyl group with a nitro group (as in ABT737); (ii) substitution of the para-aminobenzamide motif with a $1 H$-pyrrolo[2,3- $b$ ]pyridine-5-yloxy group; (iii) replacement of the morpholine and thiophenol arms with a methyl-tetrahydropyran group. Venetoclax retains the oral bioavailability of navitoclax, but is over 100-fold more selective for Bcl-2 over Bcl-xL, thus averting thrombocytopenia induced by navitoclax (167). Current clinical trials involving venetoclax are largely focused on broadening its application to include a wider variety of blood cancers, and involve both therapeutic combinations and venetoclax monotherapy (98).

Obatoclax (GX15-070) is a nonselective Bcl-2 family protein inhibitor, initially identified for its ability to inhibit Mcl-1 (127). Obatoclax features a comparatively simple scaffold compared to ABT-737 and related molecules; combined with its nonselectivity, this suggests that obatoclax may only interact with part of the binding groove present in Bcl-2 family proteins. Obatoclax has been evaluated for childhood cancers (both blood cancers and solid tumors), blood cancers in adults, and lung cancers in adults. Phase I studies indicated that the drug was well tolerated in patients with blood cancers (162), solid tumors (76), and exhibited modest single-agent activity (130). Obatoclax has been demonstrated to induce cell death in oral squamous cell carcinoma cells through a mitochondrial-dependent oxidative stress-induced mechanism (171). However, Phase II studies have generally failed to demonstrate its clinical usefulness $(59,136,163)$. Its further development was discontinued in 2013 .

S55746 (BCL-201, Servier-1) is an inhibitor developed by Servier selective for Bcl-2, built on the previously reported low-affinity, but highly Bcl-2-selective, phenylpyrazole molecule series (149). Preliminary results from a clinical trial of S55746 in patients with relapsed or refractory nonHodgkin lymphoma suggest that S55746 monotherapy is safe, tolerable, and efficacious (92). Servier has previously reported S44563, a dual Bcl-2/Bcl-xL inhibitor, an analog of ABT-737 with conformational restriction on the phenylpiperazine region (124). Given this molecule's high similarity to ABT-737, it may also exhibit similarly poor oral bioavailability, which may have prompted the identification of alternative scaffolds and the ultimate development of S55746.

(-)-Gossypol (AT-101), a terpenoid phenol derived from the cotton plant, has been shown to act as a weak inhibitor of Bcl-2 and Bcl-xL (133). In addition to acting as a BH3 mimetic, AT-101 also appears to impair DNA repair mediated by APE1, a redox-active enzyme that is a known binding partner for Bcl-2 (152, 155). Unlike ABT-737 and related molecules, which directly prevent peptide binding to Bcl-2, (-)-gossypol induces a conformational change in Bcl-2 from an antiapoptotic to a proapoptotic state (96). (-)-Gossypol was evaluated in combination with androgen deprivation therapy for the treatment of castration-sensitive metastatic prostate cancer in a Phase II clinical trial (169); the results suggested this combination was not worth further development. (-)-Gossypol has also been evaluated for the treatment of progressive or recurrent glioblastoma multiforme; the majority of patients $(62.5 \%)$ exhibited disease progression in the trial (72). (-)-Gossypol has been demonstrated to potentiate cell death induced by temozolomide (180); a Phase I clinical trial investigating this combination in the treatment of glioblastoma multiforme has been completed, but results are not currently available (23).

APG-1252 is a dual selective Bcl-2/Bcl-xL inhibitor currently under development by Ascentage Pharma Group. Limited details of this molecule have been made publicly available, however, as of this writing, recruitment is currently underway for a clinical trial of APG-1252 in patients with small-cell lung cancer and other solid tumors (70).

\section{Perspective}

It has been more than 30 years since the discovery of Bcl-2 and its association with drug resistance and aggressive hematopoietic malignancies. Over the years, the structural and functional biology of this remarkable protein has been unraveled. These pursuits have resulted in the discovery of a number of related proteins with opposing biological activities and grouped under a broader family, the Bcl-2 family. It is now well established that the balance between the pro- and 
antiapoptotic members of the family is critical in cell fate decisions, which is a function of physical interactions between proteins from within and outside of the family. While the canonical antiapoptotic activity of Bcl-2 is associated with its ability to prevent MOMP by sequestering Bax and Bak from oligomerizing at the mitochondria, recent evidence also points to a redox-dependent regulation of cell fate by Bcl-2, which appears to involve its post-translational modification. Furthermore, the altered gene expression and mutational landscape in a host of human cancer, not limited to hematopoietic malignancies, underscore the importance of Bcl-2 as an important "pro-oncogenic" protein.

Based on its interacting domains, there has been a continuous focus on developing small molecule inhibitors to overcome chemotherapy resistance induced on Bcl-2 overexpression. Bcl-2 expression has been used as a biomarker for patient response to chemotherapy. Could we now extend this to patient profiles of Bcl-2 expression in terms of ROS high and ROS low, and would this have a stronger predictive power?

There is a large body of evidence that directly links Bcl-2 and cellular redox. Earlier observations suggested an antioxidant role for Bcl-2, however, more recent work indicates a remarkable dichotomy when it comes to Bcl-2 and its effects on cellular redox metabolism. These divergent effects appear to be a function of cellular redox status itself. As such, the effect might differ under states of normoxia, hypoxia, and oxidative stress. To complicate matters further, the same ROS can have seemingly opposite effects on the antiapoptotic activity of $\mathrm{Bcl}-2 . \mathrm{H}_{2} \mathrm{O}_{2}$ in one context can cause degradation through oxidation of cysteines and promote cell death, and on the other hand can cause increased stability and promote cell survival. Similarly, the effect of an increase in $\mathrm{NO}$ and its reaction product with $\mathrm{O}_{2}{ }^{-}$, $\mathrm{OONO}^{-}$, could be associated with carbonylation or S-NO modification. Interestingly, an altered redox milieu impacts post-translational state of Bcl-2, such as its phosphorylation, which could have different functional consequences depending on whether the phosphorylation is multisite (inhibits its activity) or monosite as with serine 70 (stabilizes its activity). Based on these outcomes, it is imperative to clearly delineate the mechanisms behind the opposing effects of an altered redox state on Bcl-2 biology, particularly from the standpoint of its role in promoting chemotherapy resistance in cancer. This is even more important as many clinically approved drugs induce increases in intracellular ROS, which could fuel the process of carcinogenesis and its progression by promoting $\mathrm{Bcl}-2$ stability.

A number of promising small molecules are being developed and are undergoing clinical evaluation, however, selectivity remains a major issue. The early generation of Bcl-2 inhibitors, based on $\mathrm{BH} 3$ domain interaction, did not show the level of stringency in terms of targeting the specific antiapoptotic protein within the family. More recent approaches, such as in the case of venetoclax, appear to have addressed this issue. One possible scenario still needs attention: the reciprocal upregulation of another antiapoptotic member on specific inhibition of one. For example, is it possible that specific inhibition of $\mathrm{Bcl}-2$ might activate the compensatory upregulation of $\mathrm{Mcl}-1$ or $B c l-x L$ ? Future strategies could also leverage on the noncanonical function of Bcl-2 in terms of regulating cellular redox status. In this respect, one might envision the potential application of mo- dalities that favorably tailor the cellular redox milieu for death execution as well as overcome the inhibitory effect on putative tumor suppressors, such as the phosphatase PP2A.

\section{Acknowledgments}

Sebastian Pohl is supported by funds from the Rotary Club of Belmont, Australian Rotary Health Research Fund, and Curtin University School of Biomedical Sciences. Mark Agostino is a recipient of a Raine Priming Grant (Raine Medical Research Foundation), Operational Research Support from the Curtin Institute for Computation, and a Curtin Research Fellowship. Arun Dharmarajan is supported by strategic research funds from the School of Biomedical Sciences (Curtin University), Commercialisation Advisory Board of Curtin University and Cancer Council of Western Australia. Shazib Pervaiz is supported by research grants from the National Medical Research Council of Singapore.

\section{References}

1. Adrain C, Creagh EM, and Martin SJ. Apoptosisassociated release of Smac/DIABLO from mitochondria requires active caspases and is blocked by Bcl-2. EMBO J 20: 6627-6636, 2001.

2. Aharoni-Simon M, Shumiatcher R, Yeung A, Shih AZ, Dolinsky VW, Doucette CA, and Luciani DS. Bcl-2 regulates reactive oxygen species signaling and a redoxsensitive mitochondrial proton leak in mouse pancreatic beta-cells. Endocrinology 157: 2270-2281, 2016.

3. Albrecht H, Tschopp J, and Jongeneel CV. Bcl-2 protects from oxidative damage and apoptotic cell death without interfering with activation of NF-kappa B by TNF. FEBS Lett 351: 45-48, 1994.

4. Alibek K, Irving S, Sautbayeva Z, Kakpenova A, Bekmurzayeva A, Baiken Y, Imangali N, Shaimerdenova M, Mektepbayeva D, Balabiyev A, and Chinybayeva A. Disruption of $\mathrm{Bcl}-2$ and $\mathrm{Bcl}-\mathrm{xL}$ by viral proteins as a possible cause of cancer. Infect Agent Cancer 9: 44, 2014.

5. Almeida M, Han L, Bellido T, Manolagas SC, and Kousteni S. Wnt proteins prevent apoptosis of both uncommitted osteoblast progenitors and differentiated osteoblasts by beta-catenin-dependent and -independent signaling cascades involving Src/ERK and phosphatidylinositol 3-kinase/AKT. J Biol Chem 280: 41342-41351, 2005.

6. Amatore D, Sgarbanti R, Aquilano K, Baldelli S, Limongi D, Civitelli L, Nencioni L, Garaci E, Ciriolo MR, and Palamara AT. Influenza virus replication in lung epithelial cells depends on redox-sensitive pathways activated by NOX4-derived ROS. Cell Microbiol 17: 131-145, 2015.

7. Ambrosi E, Capaldi S, Bovi M, Saccomani G, Perduca M, and Monaco HL. Structural changes in the BH3 domain of SOUL protein upon interaction with the anti-apoptotic protein Bcl-xL. Biochem J 438: 291-301, 2011.

8. Ashkenazi A, Fairbrother WJ, Leverson JD, and Souers AJ. From basic apoptosis discoveries to advanced selective BCL-2 family inhibitors. Nat Rev Drug Discov 16: 273-284, 2017.

9. Azad N, Vallyathan V, Wang L, Tantishaiyakul V, Stehlik C, Leonard SS, and Rojanasakul Y. S-nitrosylation of Bcl2 inhibits its ubiquitin-proteasomal degradation. A novel antiapoptotic mechanism that suppresses apoptosis. $J$ Biol Chem 281: 34124-34134, 2006. 
10. Bai XC, Deng F, Liu AL, Zou ZP, Wang Y, Ke ZY, Ji QS, and Luo SQ. Phospholipase C-gamma1 is required for cell survival in oxidative stress by protein kinase C. Biochem J 363: 395-401, 2002.

11. Beck MA, Handy J, and Levander OA. The role of oxidative stress in viral infections. Ann N Y Acad Sci 917: 906-912, 2000.

12. Bellot G, Garcia-Medina R, Gounon P, Chiche J, Roux D, Pouyssegur J, and Mazure NM. Hypoxia-induced autophagy is mediated through hypoxia-inducible factor induction of BNIP3 and BNIP3 L via their BH3 domains. Mol Cell Biol 29: 2570-2581, 2009.

13. Berger S, Procko E, Margineantu D, Lee EF, Shen BW, Zelter A, Silva D-A, Chawla K, Herold MJ, Garnier J-M, Johnson R, MacCoss MJ, Lessene G, Davis TN, Stayton PS, Stoddard BL, Fairlie WD, Hockenbery DM, and Baker D. Computationally designed high specificity inhibitors delineate the roles of BCL2 family proteins in cancer. eLife 5: e20352, 2016.

14. Bondy SC and Naderi S. Contribution of hepatic cytochrome P450 systems to the generation of reactive oxygen species. Biochem Pharmacol 48: 155-159, 1994.

15. Breckenridge DG and Xue D. Regulation of mitochondrial membrane permeabilization by BCL-2 family proteins and caspases. Curr Opin Cell Biol 16: 647-652, 2004.

16. Breitschopf K, Haendeler J, Malchow P, Zeiher AM, and Dimmeler S. Posttranslational modification of Bcl-2 facilitates its proteasome-dependent degradation: molecular characterization of the involved signaling pathway. Mol Cell Biol 20: 1886-1896, 2000.

17. Browning JD and Horton JD. Molecular mediators of hepatic steatosis and liver injury. J Clin Invest 114: 147152, 2004.

18. Bruncko M, Oost TK, Belli BA, Ding H, Joseph MK, Kunzer A, Martineau D, McClellan WJ, Mitten M, Ng SC, Nimmer PM, Oltersdorf T, Park C-M, Petros AM, Shoemaker AR, Song X, Wang X, Wendt MD, Zhang H, Fesik SW, Rosenberg SH, and Elmore SW. Studies leading to potent, dual inhibitors of Bcl-2 and Bcl-xL. J Med Chem 50: 641-662, 2007.

19. Cahuana GM, Tejedo JR, Jimenez J, Ramirez R, Sobrino $F$, and Bedoya FJ. Nitric oxide-induced carbonylation of Bcl-2, GAPDH and ANT precedes apoptotic events in insulin-secreting RINm5F cells. Exp Cell Res 293: 22-30, 2004.

20. Caliceti C, Nigro P, Rizzo P, and Ferrari R. ROS, Notch, and Wnt signaling pathways: crosstalk between three major regulators of cardiovascular biology. Biomed Res Int 2014: 318714, 2014.

21. Catalano A, Rodilossi S, Caprari P, Coppola V, and Procopio A. 5-Lipoxygenase regulates senescence-like growth arrest by promoting ROS-dependent p53 activation. EMBO J 24: 170-179, 2005.

22. Catz SD and Johnson JL. Transcriptional regulation of bcl-2 by nuclear factor kappa B and its significance in prostate cancer. Oncogene 20: 7342-7351, 2001.

23. Centre SKCC. 2017. Gossypol (AT-101) and Temozolomide With or Without Radiation Therapy in Treating Patients With Newly Diagnosed Glioblastoma Multiforme. https://clinicaltrials.gov/ct2/show/NCT00390403. Access date August 21, 2017.

24. Cerami E, Gao J, Dogrusoz U, Gross BE, Sumer SO, Aksoy BA, Jacobsen A, Byrne CJ, Heuer ML, Larsson E, Antipin Y, Reva B, Goldberg AP, Sander C, and Schultz
$\mathrm{N}$. The cBio cancer genomics portal: an open platform for exploring multidimensional cancer genomics data. Cancer Discov 2: 401-404, 2012.

25. Checco JW, Lee EF, Evangelista M, Sleebs NJ, Rogers K, Pettikiriarachchi A, Kershaw NJ, Eddinger GA, Belair DG, Wilson JL, Eller CH, Raines RT, Murphy WL, Smith BJ, Gellman SH, and Fairlie WD. a/b-peptide foldamers targeting intracellular protein-protein interactions with activity in living cells. J Am Chem Soc 137: 11365-11375, 2015.

26. Chen ZX and Pervaiz S. Bcl-2 induces pro-oxidant state by engaging mitochondrial respiration in tumor cells. Cell Death Differ 14: 1617-1627, 2007.

27. Chen ZX and Pervaiz S. Involvement of cytochrome c oxidase subunits $\mathrm{Va}$ and $\mathrm{Vb}$ in the regulation of cancer cell metabolism by Bcl-2. Cell Death Differ 17: 408-420, 2010.

28. Cheng EH, Wei MC, Weiler S, Flavell RA, Mak TW, Lindsten T, and Korsmeyer SJ. BCL-2, BCL-X(L) sequester BH3 domain-only molecules preventing BAXand BAK-mediated mitochondrial apoptosis. Mol Cell 8: 705-711, 2001.

29. Choi DH, Cristovao AC, Guhathakurta S, Lee J, Joh TH, Beal MF, and Kim YS. NADPH oxidase 1-mediated oxidative stress leads to dopamine neuron death in Parkinson's disease. Antioxid Redox Signal 16: 1033-1045, 2012.

30. Chong SJ, Low IC, and Pervaiz S. Mitochondrial ROS and involvement of Bcl-2 as a mitochondrial ROS regulator. Mitochondrion 19 Pt A: 39-48, 2014.

31. Circu ML and Aw TY. Reactive oxygen species, cellular redox systems, and apoptosis. Free Radic Biol Med 48: 749-762, 2010.

32. Clearly JM, Lima CM, Hurwitz HI, Montero AJ, Franklin C, Yang J, Graham A, Busman T, Mabry M, Holen K, Shapiro GI, and Uronis H. A phase I clinical trial of navitoclax, a targeted high-affinity Bcl-2 family inhibitor, in combination with gemcitabine in patients with solid tumors. Invest New Drugs 32: 937-945, 2014.

33. Clement MV, Hirpara JL, and Pervaiz S. Decrease in intracellular superoxide sensitizes Bcl-2-overexpressing tumor cells to receptor and drug-induced apoptosis independent of the mitochondria. Cell Death Differ 10: 12731285, 2003.

34. Clement MV and Pervaiz S. Intracellular superoxide and hydrogen peroxide concentrations: a critical balance that determines survival or death. Redox Rep 6: 211-214, 2001.

35. Cooke PW, James ND, Ganesan R, Burton A, Young LS, and Wallace DM. Bcl-2 expression identifies patients with advanced bladder cancer treated by radiotherapy who benefit from neoadjuvant chemotherapy. BJU Int 85: 829$835,2000$.

36. Cox AG and Hampton MB. Bcl-2 over-expression promotes genomic instability by inhibiting apoptosis of cells exposed to hydrogen peroxide. Carcinogenesis 28: 21662171, 2007.

37. Cristofanon S, Morceau F, Scovassi AI, Dicato M, Ghibelli L, and Diederich M. Oxidative, multistep activation of the noncanonical NF-kappaB pathway via disulfide Bcl-3/p50 complex. FASEB J 23: 45-57, 2009.

38. D'Autreaux B and Toledano MB. ROS as signalling molecules: mechanisms that generate specificity in ROS homeostasis. Nat Rev Mol Cell Biol 8: 813-824, 2007. 
39. Deng X, Gao F, and May WS, Jr. Bcl 2 retards G1/S cell cycle transition by regulating intracellular ROS. Blood 102: 3179-3185, 2003.

40. Dewson G, Kratina T, Sim HW, Puthalakath H, Adams JM, Colman PM, and Kluck RM. To trigger apoptosis, Bak exposes its $\mathrm{BH} 3$ domain and homodimerizes via BH3:groove interactions. Mol Cell 30: 369-380, 2008.

41. Dias N and Stein CA. Potential role of antisense oligonucleotides in cancer therapy. The example of $\mathrm{Bcl}-2$ antisense oligonucleotides. Eur J Pharmaceut Biopharmaceut 54: 263-269, 2002.

42. Dürig H, Dührsen U, Klein-Hitpass L, Worm J, Rode Hansen JB, Ørum H, and Wissenbach M. The novel antisense Bcl-2 inhibitor SPC2996 causes rapid leukemic cell clearance and immune activation in chronic lymphocytic leukemia. Leukemia 25: 638-647, 2011.

43. Dworski R. Oxidant stress in asthma. Thorax 55 Suppl 2: S51-S53, 2000.

44. Eid H, Gulyas M, Geczi L, Bodrogi I, Institoris E, and Bak M. Expression of bcl-2 in testicular carcinoma: correlation with tumor progression and MDR1/Pgp. Cancer 83: 331336, 1998.

45. Elbim C, Pillet S, Prevost MH, Preira A, Girard PM, Rogine N, Matusani H, Hakim J, Israel N, and GougerotPocidalo MA. Redox and activation status of monocytes from human immunodeficiency virus-infected patients: relationship with viral load. J Virol 73: 4561-4566, 1999.

46. Ellerby LM, Ellerby HM, Park SM, Holleran AL, Murphy AN, Fiskum G, Kane DJ, Testa MP, Kayalar C, and Bredesen DE. Shift of the cellular oxidation-reduction potential in neural cells expressing Bcl-2. J Neurochem 67: 1259-1267, 1996.

47. Esposti MD, Hatzinisiriou I, McLennan H, and Ralph S. Bcl-2 and mitochondrial oxygen radicals. New approaches with reactive oxygen species-sensitive probes. J Biol Chem 274: 29831-29837, 1999.

48. Fernandez V, Tapia G, Varela P, Castillo I, Mora C, Moya F, Orellana M, and Videla LA. Redox up-regulated expression of rat liver manganese superoxide dismutase and Bcl-2 by thyroid hormone is associated with inhibitor of kappaB-alpha phosphorylation and nuclear factor-kappaB activation. J Endocrinol 186: 539-547, 2005.

49. Follis AV, Chipuk JE, Fisher JC, Yun MK, Grace CR, Nourse A, Baran K, Ou L, Min L, White SW, Green DR, and Kriwacki RW. PUMA binding induces partial unfolding within BCL-xL to disrupt p53 binding and promote apoptosis. Nat Chem Biol 9: 163-168, 2013.

50. Follis AV, Llambi F, Ou L, Baran K, Green DR, and Kriwacki RW. The DNA-binding domain mediates both nuclear and cytosolic functions of p53. Nat Struct Mol Biol 21: 535-543, 2014.

51. Frantz S. Lessons learnt from Genasense's failure. Nat Rev Drug Discov 3: 542-543, 2004.

52. Funato Y, Michiue T, Asashima M, and Miki H. The thioredoxin-related redox-regulating protein nucleoredoxin inhibits Wnt-beta-catenin signalling through dishevelled. Nat Cell Biol 8: 501-508, 2006.

53. Gao J, Aksoy BA, Dogrusoz U, Dresdner G, Gross B, Sumer SO, Sun Y, Jacobsen A, Sinha R, Larsson E, Cerami E, Sander C, and Schultz N. Integrative analysis of complex cancer genomics and clinical profiles using the cBioPortal. Sci Signal 6: pl1, 2013.

54. Gardner A, Xu FH, Fady C, Sarafian T, Tu Y, and Lichtenstein A. Evidence against the hypothesis that BCL-2 inhibits apoptosis through an anti-oxidant effect. Cell Death Differ 4: 487-496, 1997.

55. Ghosh R, Alajbegovic A, and Gomes AV. NSAIDs and cardiovascular diseases: role of reactive oxygen species. Oxid Med Cell Longev 2015: 536962, 2015.

56. Glasauer A, Sena LA, Diebold LP, Mazar AP, and Chandel NS. Targeting SOD1 reduces experimental nonsmall-cell lung cancer. J Clin Invest 124: 117-128, 2014.

57. Gong G, Waris G, Tanveer R, and Siddiqui A. Human hepatitis $\mathrm{C}$ virus NS5A protein alters intracellular calcium levels, induces oxidative stress, and activates STAT-3 and NF-kappa B. Proc Natl Acad Sci U S A 98: 9599-9604, 2001.

58. Gouaze V, Andrieu-Abadie N, Cuvillier O, MalagarieCazenave S, Frisach MF, Mirault ME, and Levade T. Glutathione peroxidase-1 protects from CD95-induced apoptosis. J Biol Chem 277: 42867-42874, 2002.

59. Goy A, Hernandez-Ilzaliturri FJ, Kahl B, Ford P, Protomastro E, and Berger M. A phase I/II study of the pan Bcl-2 inhibitor obatoclax mesylate plus bortezomib for relapsed or refractory mantle cell lymphoma. Leukemia Lymphoma 55: 2761-2768, 2014.

60. Grivennikova VG and Vinogradov AD. Generation of superoxide by the mitochondrial Complex I. Biochim Biophys Acta 1757: 553-561, 2006.

61. Halliwell B and Cross CE. Oxygen-derived species: their relation to human disease and environmental stress. Environ Health Perspect 102 Suppl 10: 5-12, 1994.

62. Harrison D, Griendling KK, Landmesser U, Hornig B, and Drexler H. Role of oxidative stress in atherosclerosis. Am J Cardiol 91: 7A-11A, 2003.

63. Heckman CA, Mehew JW, and Boxer LM. NF-kappaB activates Bcl-2 expression in $\mathrm{t}(14 ; 18)$ lymphoma cells. Oncogene 21: 3898-3908, 2002.

64. Hennet T, Peterhans E, and Stocker R. Alterations in antioxidant defences in lung and liver of mice infected with influenza A virus. J Gen Virol 73 (Pt 1): 39-46, 1992.

65. Herzenberg LA, De Rosa SC, Dubs JG, Roederer M, Anderson MT, Ela SW, Deresinski SC, and Herzenberg LA. Glutathione deficiency is associated with impaired survival in HIV disease. Proc Natl Acad Sci U S A 94: 1967-1972, 1997.

66. Hildeman DA, Mitchell T, Aronow B, Wojciechowski S, Kappler J, and Marrack P. Control of Bcl-2 expression by reactive oxygen species. Proc Natl Acad Sci U S A 100: 15035-15040, 2003.

67. Hockenbery D, Nunez G, Milliman C, Schreiber RD, and Korsmeyer SJ. Bcl-2 is an inner mitochondrial membrane protein that blocks programmed cell death. Nature 348: 334-336, 1990.

68. Hockenbery DM, Oltvai ZN, Yin XM, Milliman CL, and Korsmeyer SJ. Bcl-2 functions in an antioxidant pathway to prevent apoptosis. Cell 75: 241-251, 1993.

69. Ichimiya M, Chang SH, Liu H, Berezesky IK, Trump BF, and Amstad PA. Effect of Bcl-2 on oxidant-induced cell death and intracellular Ca2+ mobilization. Am J Physiol 275: C832-C839, 1998.

70. Inc. APG. 2017. A study of APG-1252 in patients with SCLC or other solid tumors. https://clinicaltrials.gov/ct2/ show/NCT03080311. Access date August 21, 2017.

71. Inoguchi T, Sonta T, Tsubouchi H, Etoh T, Kakimoto M, Sonoda N, Sato N, Sekiguchi N, Kobayashi K, Sumimoto $\mathrm{H}$, Utsumi H, and Nawata H. Protein kinase C-dependent increase in reactive oxygen species (ROS) production in 
vascular tissues of diabetes: role of vascular NAD $(\mathrm{P}) \mathrm{H}$ oxidase. J Am Soc Nephrol 14: S227-S232, 2003.

72. Institute NC. 2017. Gossypol in treating patients with progressive or recurrent glioblastoma multiforme. https:// clinicaltrials.gov/ct2/show/NCT00540722. Access date August 21, 2017.

73. Jang JH and Surh YJ. Bcl-2 attenuation of oxidative cell death is associated with up-regulation of gamma-glutamylcysteine ligase via constitutive NF-kappaB activation. $J$ Biol Chem 279: 38779-38786, 2004.

74. Jiang TY, Liu MH, J.P. W, and Shi YG. Structural and biochemical analysis of Bcl-2 interaction with the hepatitis B virus protein HBx. Proc Natl Acad Sci USA 113: 2074-2079, 2016.

75. Joza N, Susin SA, Daugas E, Stanford WL, Cho SK, Li CY, Sasaki T, Elia AJ, Cheng HY, Ravagnan L, Ferri KF, Zamzami N, Wakeham A, Hakem R, Yoshida H, Kong YY, Mak TW, Zuniga-Pflucker JC, Kroemer G, and Penninger JM. Essential role of the mitochondrial apoptosisinducing factor in programmed cell death. Nature 410: 549-554, 2001.

76. Kaik PK, Rudin CM, Brown A, Rizvi NA, Takebe N, Travis W, James L, Ginsberg MS, Juergens R, Markus S, Tyson L, Subzwari S, Kris MG, and Krug LM. A phase I study of obatoclax mesylate, a Bcl-2 antagonist, plus toptecan in solid tumor malignancies. Cancer Chemother Pharmacol 66: 1079-1085, 2010.

77. Kane DJ, Sarafian TA, Anton R, Hahn H, Gralla EB, Valentine JS, Ord T, and Bredesen DE. Bcl-2 inhibition of neural death: decreased generation of reactive oxygen species. Science 262: 1274-1277, 1993.

78. Kang DH, Lee DJ, Lee S, Lee SY, Jun Y, Kim Y, Kim Y, Lee JS, Lee DK, Lee S, Jho EH, Yu DY, and Kang SW. Interaction of tankyrase and peroxiredoxin II is indispensable for the survival of colorectal cancer cells. Nat Commun 8: 40, 2017.

79. Kang J, Chong SJ, Ooi VZ, Vali S, Kumar A, Kapoor S, Abbasi T, Hirpara JL, Loh T, Goh BC, and Pervaiz S. Overexpression of Bcl-2 induces STAT-3 activation via an increase in mitochondrial superoxide. Oncotarget 6: 34191-34205, 2015.

80. Karbowski M, Norris KL, Cleland MM, Jeong SY, and Youle RJ. Role of Bax and Bak in mitochondrial morphogenesis. Nature 443: 658-662, 2006.

81. Kaufmann JA, Bickford PC, and Taglialatela G. Oxidative-stress-dependent up-regulation of Bcl-2 expression in the central nervous system of aged Fisher-344 rats. J Neurochem 76: 1099-1108, 2001.

82. Kelkel M, Cerella C, Mack F, Schneider T, Jacob C, Schumacher M, Dicato M, and Diederich M. ROSindependent JNK activation and multisite phosphorylation of Bcl-2 link diallyl tetrasulfide-induced mitotic arrest to apoptosis. Carcinogenesis 33: 2162-2171, 2012.

83. Kluck RM, Bossy-Wetzel E, Green DR, and Newmeyer DD. The release of cytochrome c from mitochondria: a primary site for Bcl-2 regulation of apoptosis. Science 275: 1132-1136, 1997.

84. Koh LW, Koh GR, Ng FS, Toh TB, Sandanaraj E, Chong YK, Phong M, Tucker-Kellogg G, Kon OL, Ng WH, Ng IH, Clement MV, Pervaiz S, Ang BT, and Tang CS. A distinct reactive oxygen species profile confers chemoresistance in glioma-propagating cells and associates with patient survival outcome. Antioxid Redox Signal 19: 2261-2279, 2013.
85. Kowaltowski AJ, Castilho RF, and Vercesi AE. Mitochondrial permeability transition and oxidative stress. FEBS Lett 495: 12-15, 2001.

86. $\mathrm{Ku} \mathrm{B}$, Liang C, Jung JU, and Oh BH. Evidence that inhibition of Bax activation by Bcl-2 involves its tight and preferential interaction with the $\mathrm{BH} 3$ domain of Bax. Cell Res 21: 627, 2011.

87. Kubli DA, Quinsay MN, Huang C, Lee Y, and Gustafsson AB. Bnip3 functions as a mitochondrial sensor of oxidative stress during myocardial ischemia and reperfusion. Am J Physiol Heart Circ Physiol 295: H2025-H2031, 2008.

88. Kuppusamy $\mathrm{P}$ and Zweier JL. Characterization of free radical generation by xanthine oxidase. Evidence for hydroxyl radical generation. J Biol Chem 264: 9880-9884, 1989.

89. Kwon T, Rho JK, Lee JC, Park YH, Shin HJ, Cho S, Kang YK, Kim BY, Yoon DY, and Yu DY. An important role for peroxiredoxin II in survival of A549 lung cancer cells resistant to gefitinib. Exp Mol Med 47: e165, 2015.

90. Lai JC, Benimetskaya L, Santella RM, Wang Q, Miller PS, and Stein CA. G3139 (oblimersen) may inhibit prostate cancer cell growth in a partially bis-CpG-dependent non-antisense manner. Mol Cancer Ther 2: 1031-1043, 2003.

91. Lambeth JD. NOX enzymes and the biology of reactive oxygen. Nat Rev Immunol 4: 181-189, 2004.

92. Le Gouill S, Wermke M, Morschhauser F, Lim ST, Salles G, Kloos I, de Burgat V, Becquart M, Paux G, KrausBerthier L, Pennaforte S, Stilgenbauer S, Walewski J, and Ribrag V. A new Bcl-2 inhibitor (S55746/BCL201) as monotherapy in patients with relapsed or refractory nonHodgkin lymphoma: preliminary results of the first-inhuman study. Haematol Oncol 35(S2): 47-48, 2017.

93. Lee EF, Dewson G, Evangelista M, Pettikiriarachchi A, Zhu H, Colman PM, and Fairlie WD. The functional difference of pro-survival and pro-apoptotic B cell lymphoma 2 (Bcl-2) proteins depend on structural differences in their Bcl-2 homology 3 (Bh3) domains. J Biol Chem 289: 36001-36017, 2014.

94. Lee EF, Sadowsky JD, Smith BJ, Czabotar PE, PetersonKaufman KJ, Colman PM, Gellman SH, and Fairlie WD. High-resolution structural characterization of a helical a/ b-peptide foldamer bound to the anti-apoptotic protein Bcl-x(L). Angew Chem Int Ed 48: 4318-4322, 2009.

95. Lee M, Hyun DH, Marshall KA, Ellerby LM, Bredesen DE, Jenner P, and Halliwell B. Effect of overexpression of BCL-2 on cellular oxidative damage, nitric oxide production, antioxidant defenses, and the proteasome. Free Radic Biol Med 31: 1550-1559, 2001.

96. Lei X, Chen Y, Du G, Yu W, Wang X, Qu H, Xia B, He H, Mao J, Zong W, Liao X, Mehrpour M, Hao X, and Chen Q. Gossypol induces Bax/Bak-independent activation of apoptosis and cytochrome c release via a conformational change in Bcl-2. FASEB J 20: E1510-E1519, 2006.

97. Levine B, Sinha S, and Kroemer G. Bcl-2 family members: dual regulators of apoptosis and autophagy. Autophagy 4: 600-606, 2008.

98. Levy MA and Claxton DF. Therapeutic inhibition of BCL-2 and related family members. Expert Opin Investigat Drugs 26: 293-301, 2017.

99. Li Y, Lu Z, Chen F, Guan J, Hu L, Xu Y, and Chen J. Antisense bcl-2 transfection up-regulates anti-apoptotic 
and anti-oxidant thioredoxin in neuroblastoma cells. $J$ Neurooncol 72: 17-23, 2005.

100. Liang J, Cao R, Wang X, Zhang Y, Wang P, Gao H, Li C, Yang F, Zeng R, Wei P, Li D, Li W, and Yang W. Mitochondrial PKM2 regulates oxidative stress-induced apoptosis by stabilizing Bcl2. Cell Res 27: 329-351, 2017.

101. Limongi D and Baldelli S. Redox Imbalance and Viral Infections in Neurodegenerative Diseases. Oxid Med Cell Longev 2016: 6547248, 2016.

102. Liou GY and Storz P. Reactive oxygen species in cancer. Free Radic Res 44: 479-496, 2010.

103. Lipinski CA, Lombardo F, Dominy BW, and Feeney PJ. Experimental and computational approaches to estimate solubility and permeability in drug discovery and development settings. Adv Drug Deliv Rev 23: 3-25, 1997.

104. Longoni B, Boschi E, Demontis GC, Marchiafava PL, and Mosca F. Regulation of Bcl-2 protein expression during oxidative stress in neuronal and in endothelial cells. Biochem Biophys Res Commun 260: 522-526, 1999.

105. Lopez-Otin C, Blasco MA, Partridge L, Serrano M, and Kroemer G. The hallmarks of aging. Cell 153: 1194-1217, 2013.

106. Low IC, Kang J, and Pervaiz S. Bcl-2: a prime regulator of mitochondrial redox metabolism in cancer cells. Antioxid Redox Signal 15: 2975-2987, 2011.

107. Low IC, Loh T, Huang Y, Virshup DM, and Pervaiz S. Ser70 phosphorylation of Bcl-2 by selective tyrosine nitration of PP2A-B56delta stabilizes its antiapoptotic activity. Blood 124: 2223-2234, 2014.

108. Lu Y, Rolland SG, and Conradt B. A molecular switch that governs mitochondrial fusion and fission mediated by the BCL2-like protein CED-9 of Caenorhabditis elegans. Proc Natl Acad Sci U S A 108: E813-E822, 2011.

109. Luanpitpong S, Chanvorachote P, Stehlik C, Tse W, Callery PS, Wang L, and Rojanasakul Y. Regulation of apoptosis by Bcl-2 cysteine oxidation in human lung epithelial cells. Mol Biol Cell 24: 858-869, 2013.

110. Manna SK, Zhang HJ, Yan T, Oberley LW, and Aggarwal BB. Overexpression of manganese superoxide dismutase suppresses tumor necrosis factor-induced apoptosis and activation of nuclear transcription factorkappaB and activated protein-1. J Biol Chem 273: 13245-13254, 1998.

111. Mari M, Morales A, Colell A, Garcia-Ruiz C, and Fernandez-Checa JC. Mitochondrial glutathione, a key survival antioxidant. Antioxid Redox Signal 11: 26852700, 2009.

112. Markesbery WR. Oxidative stress hypothesis in Alzheimer's disease. Free Radic Biol Med 23: 134-147, 1997.

113. Markou T, Dowling AA, Kelly T, and Lazou A. Regulation of Bcl-2 phosphorylation in response to oxidative stress in cardiac myocytes. Free Radic Res 43: 809-816, 2009.

114. Maundrell K, Antonsson B, Magnenat E, Camps M, Muda M, Chabert C, Gillieron C, Boschert U, Vial-Knecht E, Martinou JC, and Arkinstall S. Bcl-2 undergoes phosphorylation by c-Jun N-terminal kinase/stress-activated protein kinases in the presence of the constitutively active GTP-binding protein Rac1. J Biol Chem 272: 2523825242, 1997.

115. McDonnell TJ, Deane N, Platt FM, Nunez G, Jaeger U, McKearn JP, and Korsmeyer SJ. bcl-2-immunoglobulin transgenic mice demonstrate extended B cell survival and follicular lymphoproliferation. Cell 57: 79-88, 1989.
116. Messmer UK, Reed UK, and Brune B. Bcl-2 protects macrophages from nitric oxide-induced apoptosis. J Biol Chem 271: 20192-20197, 1996.

117. Mikhailov V, Mikhailova M, Pulkrabek DJ, Dong Z, Venkatachalam MA, and Saikumar P. Bcl-2 prevents Bax oligomerization in the mitochondrial outer membrane. $J$ Biol Chem 276: 18361-18374, 2001.

118. Miriyala S, Spasojevic I, Tovmasyan A, Salvemini D, Vujaskovic Z, St Clair D, and Batinic-Haberle I. Manganese superoxide dismutase, MnSOD and its mimics. Biochim Biophys Acta 1822: 794-814, 2012.

119. Muchmore SW, Sattler M, Liang H, Meadows RP, Harlan JE, Yoon HS, Nettesheim D, Chang BS, Thompson CB, Wong SL, Ng SL, and Fesik SW. X-ray and NMR structure of human Bcl-xL, an inhibitor of programmed cell death. Nature 381: 335-341, 1996.

120. Muller FL, Liu Y, and Van Remmen H. Complex III releases superoxide to both sides of the inner mitochondrial membrane. J Biol Chem 279: 49064-49073, 2004.

121. Murphy MP. How mitochondria produce reactive oxygen species. Biochem J 417: 1-13, 2009.

122. Myers KM, Fiskum G, Liu Y, Simmens SJ, Bredesen DE, and Murphy AN. Bcl-2 protects neural cells from cyanide/ aglycemia-induced lipid oxidation, mitochondrial injury, and loss of viability. J Neurochem 65: 2432-2440, 1995.

123. Nakamura H, Masutani H, and Yodoi J. Redox imbalance and its control in HIV infection. Antioxid Redox Signal 4: 455-464, 2002.

124. Némati F, de Montrion C, Lang G, Kraus-Berthier L, Carita G, Sastre-Garau X, Berniard A, Vallerand D, Geneste O, de Plater L, Pierré A, Lockhart B, Desjardins L, Piperno-Neumann S, Depil S, and Decaudin D. Targeting $\mathrm{Bcl}-2 / \mathrm{Bcl}-\mathrm{X}_{\mathrm{L}}$ induces antitumor activity in uveal melanoma patient-derived xenografts. PLoS One 9: e80836, 2014.

125. Nencioni L, De Chiara G, Sgarbanti R, Amatore D, Aquilano K, Marcocci ME, Serafino A, Torcia M, Cozzolino F, Ciriolo MR, Garaci E, and Palamara AT. Bcl-2 expression and p38MAPK activity in cells infected with influenza A virus: impact on virally induced apoptosis and viral replication. J Biol Chem 284: 16004-16015, 2009.

126. Nencioni L, Iuvara A, Aquilano K, Ciriolo MR, Cozzolino F, Rotilio G, Garaci E, and Palamara AT. Influenza A virus replication is dependent on an antioxidant pathway that involves GSH and Bcl-2. FASEB $J$ 17: 758-760, 2003.

127. Nguyen M, Marcellus RC, Roulston A, Watson M, Serfass L, Murthy Madiraju SR, Gouley D, Viallet J, Bélec L, Billot X, Acoca S, Purisima E, Wiegmans A, Cluse L, Johnstone RW, Beauparlant P, and Shore GC. Small molecule obatoclax (GX15-070) antagonizes MCL-1 and overcomes MCL-1-mediated resistance to apoptosis. Proc Natl Acad Sci USA 104: 19512-19517, 2007.

128. Ni Z, Wang B, Dai X, Ding W, Yang T, Li X, Lewin S, $\mathrm{Xu} \mathrm{L}$, Lian J, and He F. HCC cells with high levels of Bcl2 are resistant to ABT-737 via activation of the ROS-JNKautophagy pathway. Free Radic Biol Med 70: 194-203, 2014.

129. Niture SK and Jaiswal AK. Nrf2 protein up-regulates antiapoptotic protein $\mathrm{Bcl}-2$ and prevents cellular apoptosis. J Biol Chem 287: 9873-9886, 2012.

130. O'Brien SM, Claxton DF, Crump M, Faderl S, Kipps T, Keating MJ, Viallet J, and Cheson BD. Phase I study of obatoclax mesylate (GX15-070), a small molecular 
pan-Bcl-2 family antagonist, in patients with advanced chronic lympocytic leukemia. Blood 113: 299-305, 2009.

131. O’Neill JW, Manion MK, Maguire B, and Hockenbery DM. BCL-XL dimerization by three-dimensional domain swapping. J Mol Biol 356: 367-381, 2006.

132. Oberstein A, Jeffrey PD, and Shi Y. Crystal structure of the Bcl-XL-Beclin 1 peptide complex: beclin 1 is a novel BH3-only protein. J Biol Chem 282: 1312313132, 2007.

133. Oliver CL, Miranda MB, Shangary S, Land S, Wang S, and Johnson DE. (-)-Gossypol acts directly on the mitochondria to overcome $\mathrm{Bcl}-2$ - and $\mathrm{Bcl}-\mathrm{X}(\mathrm{L})-$ mediated apoptosis resistance. Mol Cancer Ther 4: 2331, 2005.

134. Oltersdorf T, Elmore SW, Shoemaker AR, Armstrong RC, Augeri DJ, Belli BA, Bruncko M, Deckwerth TL, Dinges J, Hajduk PJ, Joseph MK, Kitada S, Korsmeyer SJ, Kunzer AR, Letai A, Li C, Mitten MJ, Nettesheim DG, Ng S, Nimmer PM, O'Connor JM, Oleksijew A, Petros AM, Reed JC, Shen W, Tahir SK, Thompson CB, Tomaselli KJ, Wang B, Wendt MD, Zhang H, Fesik SW, and Rosenberg SH. An inhibitor of Bcl-2 family proteins induces regression of solid tumours. Nature 435: 677-681, 2005.

135. Oltvai ZN, Milliman CL, and Korsmeyer SJ. Bcl-2 heterodimerizes in vivo with a conserved homolog, Bax, that accelerates programmed cell death. Cell 74: 609-619, 1993.

136. Paik PK, Rudin CM, Pietanza MC, Brown A, Rizvi NA, Takebe N, Travis W, James L, Ginsberg MS, Juergens R, Markus S, Tyson L, Subzwari S, Kris MG, and Krug LM. A phase II study of obatoclax mesylate, a Bcl-2 antagonist, plus toptecan in relapsed small cell lung cancer. Lung Cancer 74: 481-485, 2011.

137. Park C-M, Bruncko M, Adickes J, Bauch J, Ding H, Kunzer A, Marsh KC, Nimmer P, Shoemaker AR, Song X, Tahir SK, Tse C, Wang X, Wendt MD, Yang X, Zhang H, Fesik SW, Rosenberg SH, and Elmore SW. Discovery of an orally bioavailable small molecule inhibitor of prosurvival B-cell lymphoma 2 proteins. J Med Chem 51: 6902-6915, 2008.

138. Pasinelli P, Belford ME, Lennon N, Bacskai BJ, Hyman BT, Trotti D, and Brown RH, Jr. Amyotrophic lateral sclerosis-associated SOD1 mutant proteins bind and aggregate with Bcl-2 in spinal cord mitochondria. Neuron 43: 19-30, 2004.

139. Pattingre S, Tassa A, Qu X, Garuti R, Liang XH, Mizushima N, Packer M, Schneider MD, and Levine B. Bcl2 antiapoptotic proteins inhibit Beclin 1-dependent autophagy. Cell 122: 927-939, 2005.

140. Pedrini S, Sau D, Guareschi S, Bogush M, Brown RH, Jr., Naniche N, Kia A, Trotti D, and Pasinelli P. ALS-linked mutant SOD1 damages mitochondria by promoting conformational changes in Bcl-2. Hum Mol Genet 19: 2974 2986, 2010.

141. Perez HL, Banfi P, Bertrand JA, Cai ZW, Grebinski JW, Kim K, Lippy J, Modugno M, Naglich J, Schmidt RJ, Tebben A, Vianello P, Wei DD, Zhang L, Galvani A, Lombardo LJ, and Borzilleri RM. Identification of a phenylacylsulfonamide series of dual Bcl-2/ Bcl-Xl antagonists. Bioorg Med Chem Lett 22: 3946, 2012.

142. Pervaiz S. Pro-oxidant milieu blunts scissors: insight into tumor progression, drug resistance, and novel druggable targets. Curr Pharm Des 12: 4469-4477, 2006.
143. Pervaiz S, Cao J, Chao OS, Chin YY, and Clement MV. Activation of the RacGTPase inhibits apoptosis in human tumor cells. Oncogene 20: 6263-6268, 2001.

144. Pervaiz S and Clement MV. A permissive apoptotic environment: function of a decrease in intracellular superoxide anion and cytosolic acidification. Biochem Biophys Res Commun 290: 1145-1150, 2002.

145. Pervaiz S and Clement MV. Superoxide anion: oncogenic reactive oxygen species? Int J Biochem Cell Biol 39: 1297-1304, 2007.

146. Petros AM, Medek A, Nettesheim DG, Kim DH, Yoon HS, Swift K, Matayoshi ED, Oltersdorf T, and Fesik SW. Solution structure of the antiapoptotic protein bcl-2. Proc Natl Acad Sci USA 98: 3012-3017, 2001.

147. Petros AM, Nettesheim DG, Wang Y, Olejniczak ET, Meadows RP, Mack J, Swift K, Matayoshi ED, Zhang H, Thompson CB, and Fesik SW. Rationale for Bcl-xL/Bad peptide complex formation from structure, mutagenesis, and biophysical studies. Protein Sci 9: 2528-2534, 2000.

148. Pierce RH, Vail ME, Ralph L, Campbell JS, and Fausto N. Bcl-2 expression inhibits liver carcinogenesis and delays the development of proliferating foci. Am J Pathol 160: 1555-1560, 2002.

149. Porter J, Payne A, de Candole B, Ford D, Hutchinson B, Trevitt G, Turner J, Edwards C, Watkins C, Whitcombe I, Davis J, and Stubberfield C. Tetrahydroisoquinoline amide substituted phenyl pyrazoles as selective Bcl-2 inhibitors. Bioorg Med Chem Lett 19: 230-233, 2009.

150. Pugazhenthi S, Nesterova A, Jambal P, Audesirk G, Kern M, Cabell L, Eves E, Rosner MR, Boxer LM, and Reusch JE. Oxidative stress-mediated down-regulation of bcl-2 promoter in hippocampal neurons. J Neurochem 84: 982996, 2003.

151. Pugazhenthi S, Nesterova A, Sable C, Heidenreich KA, Boxer LM, Heasley LE, and Reusch JE. Akt/protein kinase B up-regulates Bcl-2 expression through cAMPresponse element-binding protein. J Biol Chem 275: 10761-10766, 2000.

152. Qian C, Li M, Sui J, Ren T, Li Z, Zhang L, Zhou L, Cheng $\mathrm{Y}$, and Wang D. Identification of a novel potential antitumor activity of gossypol as an APE1/Ref-1 inhibitor. Drug Des Devel Ther 8: 485-496, 2014.

153. Ray PD, Huang BW, and Tsuji Y. Reactive oxygen species (ROS) homeostasis and redox regulation in cellular signaling. Cell Signal 24: 981-990, 2012.

154. Reczek CR and Chandel NS. ROS-dependent signal transduction. Curr Opin Cell Biol 33: 8-13, 2015.

155. Ren T, Shan J, Li M, Qing Y, Qian C, Wang G, Li Q, Lu G, Li C, Peng Y, Luo H, Zhang S, Yang Y, Cheng Y, Wang D, and Zhou SF. Small-molecule BH3 mimetic and pan-Bcl-2 inhibitor AT-101 enhances the antitumor efficacy of cisplatin through inhibition of APE1 repair and redox activity in non-small-cell lung cancer. Drug Des Devel Ther 9: 2887-2910, 2015.

156. Rhee SG. Cell signaling. $\mathrm{H} 2 \mathrm{O} 2$, a necessary evil for cell signaling. Science 312: 1882-1883, 2006.

157. Rimpler MM, Rauen U, Schmidt T, Moroy $\mathrm{T}$, and de Groot $\mathrm{H}$. Protection against hydrogen peroxide cytotoxicity in rat-1 fibroblasts provided by the oncoprotein Bcl2: maintenance of calcium homoeostasis is secondary to the effect of Bcl-2 on cellular glutathione. Biochem J 340 (Pt 1): 291-297, 1999.

158. Roberts AW, Seymour JF, Brown JR, Wierda WG, Kipps TJ, Khaw SL, Carney DA, He SZ, Huang DC, Xiong 
H, Cui Y, Busman TA, McKeegan EM, Krivoshik AP, Enschede SH, and Humerickhouse RA. Substantial susceptibility of chronic lymphocytic leukemia to BCL2 inhibition: results of a phase I study of navitoclax in patients with relapsed or refractory disease. J Clin Oncol 10: 488-496, 2012.

159. Rolland SG and Conradt B. New role of the BCL2 family of proteins in the regulation of mitochondrial dynamics. Curr Opin Cell Biol 22: 852-858, 2010.

160. Rudin CM, Yang Z, Schumaker LM, VanderWeele DJ, Newkirk K, Egorin MJ, Zuhowski EG, and Cullen KJ. Inhibition of glutathione synthesis reverses Bcl-2mediated cisplatin resistance. Cancer Res 63: 312-318, 2003.

161. Sattler M, Liang H, Nettesheim D, Meadows RP, Harlan JE, Eberstadt M, Yoon HS, Shuker SB, Chang BS, Minn AJ, Thompson CB, and Fesik SW. Structure of Bcl-xLBak peptide complex: recognition between regulators of apoptosis. Science 275: 983-986, 1997.

162. Schimmer AD, O'Brien S, Kantarijan H, Brandwein J, Cheson BD, Minden MD, Yee K, Ravandi F, Giles F, Schuh A, Gupta V, Adreeff M, Koller C, Chang H, Kamel-Reid S, Berger M, Viallet J, and Borthakur G. A phase I study of the pan bcl-2 family inhibitor obatoclax mesylate in patients with advanced hematologic malignancies. Clin Cancer Res 14: 8295-8301, 2008.

163. Schimmer AD, Raza A, Carter TH, Claxton DF, Erba H, DeAngelo DJ, Tallman MS, Goard C, and Borthakur G. A multicenter phase I/II study of obatoclax mesylate administered as a 3- or 24-hour infusion in older patients with previously untreated acute myeloid leukemia. PLoS One 9: e108694, 2014.

164. Sheridan C, Delivani P, Cullen SP, and Martin SJ. Bax- or Bak-induced mitochondrial fission can be uncoupled from cytochrome C release. Mol Cell 31: 570-585, 2008.

165. Shimizu S, Eguchi Y, Kamiike W, Funahashi Y, Mignon A, Lacronique V, Matsuda $\mathrm{H}$, and Tsujimoto $\mathrm{Y}$. Bcl-2 prevents apoptotic mitochondrial dysfunction by regulating proton flux. Proc Natl Acad Sci U S A 95: 1455-1459, 1998.

166. Son YO, Pratheeshkumar P, Wang L, Wang X, Fan J, Kim DH, Lee JY, Zhang Z, Lee JC, and Shi X. Reactive oxygen species mediate $\mathrm{Cr}(\mathrm{VI})$-induced carcinogenesis through PI3K/AKT-dependent activation of GSK-3beta/ beta-catenin signaling. Toxicol Appl Pharmacol 271: 239248, 2013.

167. Souers AJ, Leverson JD, Boghaert ER, Ackler SL, Catron ND, Chen J, Dayton BD, Ding H, Enschede SH, Fairbrother WJ, Huang DC, Hymowitz SG, Jin S, Khaw SL, Kovar PJ, Lam LT, Lee J, Maecker HL, Marsh KC, Mason KD, Mitten MJ, Nimmer PM, Oleksijew A, Park CH, Park CM, Phillips DC, Roberts AW, Sampath D, Seymour JF, Smith ML, Sullivan GM, Tahir SK, Tse C, Wendt MD, Xiao Y, Xue JC, Zhang H, Humerickhouse RA, Rosenberg SH, and Elmore SW. ABT-199, a potent and selective BCL-2 inhibitor, achieves antitumor activity while sparing platelets. Nat Med 19: 202-208, 2013.

168. Stehbens WE. Oxidative stress in viral hepatitis and AIDS. Exp Mol Pathol 77: 121-132, 2004.

169. Stein MN, Hussain M, Stadler WM, Liu G, Tereshchenko IV, Goodin S, Jeyamohan C, Kaufman HL, Mehnert J, and DiPaola R.S. A Phase II study of AT-101 to overcome Bcl-2 mediated resistance to androgen deprivation therapy in patients with newly diagnosed castration sensitive metastatic prostate cancer. Clin Genitourin Cancer 14: 22-27, 2016.

170. Steinman HM. The Bcl-2 oncoprotein functions as a prooxidant. J Biol Chem 270: 3487-3490, 1995.

171. Sulkshane P and Teni T. BH3 mimetic Obatoclax (GX15070) mediates mitochondrial stress predominantly via MCL-1 inhibition and induces autophagy-dependent necroptosis in human oral cancer cells. Oncotarget 8: 60060-60079, 2017.

172. Szabo C, Ischiropoulos H, and Radi R. Peroxynitrite: biochemistry, pathophysiology and development of therapeutics. Nat Rev Drug Discov 6: 662-680, 2007.

173. Touré BB, Miller-Moslin K, Yussuff N, Perez L, Doré M, Joud C, Michael W, DiPietro L, van der Plas S, McEwan M, Lenoir F, Hoe M, Karki R, Springer C, Sullivan J, Levine K, Fiorilla C, Xie X, Kulathila R, Herlihy K, Porter D, and Visser M. The role of the acidity of Nheteroaryl sulfonamides as inhibitors of $\mathrm{Bcl}-2$ family protein-protein interactions. ACS Med Chem Lett 4: 186190, 2013.

174. Tsujimoto Y, Cossman J, Jaffe E, and Croce CM. Involvement of the bcl-2 gene in human follicular lymphoma. Science 228: 1440-1443, 1985.

175. Tsujimoto Y, Finger LR, Yunis J, Nowell PC, and Croce $\mathrm{CM}$. Cloning of the chromosome breakpoint of neoplastic B cells with the $\mathrm{t}(14 ; 18)$ chromosome translocation. Science 226: 1097-1099, 1984.

176. Tzung SP, Kim KM, Basanez G, Giedt CD, Simon J, Zimmerberg J, Zhang KY, and Hockenbery DM. Antimycin A mimics a cell-death-inducing Bcl-2 homology domain 3. Nat Cell Biol 3: 183-191, 2001.

177. Vail ME, Chaisson ML, Thompson J, and Fausto N. Bcl-2 expression delays hepatocyte cell cycle progression during liver regeneration. Oncogene 21: 15481555, 2002.

178. Velaithan R, Kang J, Hirpara JL, Loh T, Goh BC, Le Bras M, Brenner C, Clement MV, and Pervaiz S. The small GTPase Rac1 is a novel binding partner of Bcl-2 and stabilizes its antiapoptotic activity. Blood 117: 62146226, 2011.

179. Voehringer DW, McConkey DJ, McDonnell TJ, Brisbay $\mathrm{S}$, and Meyn RE. Bcl-2 expression causes redistribution of glutathione to the nucleus. Proc Natl Acad Sci U S A 95: 2956-2960, 1998.

180. Voss V, Senft C, Lang V, Ronellenfitsch MW, Steinbach JP, Seifert V, and Kögel D. The pan-Bcl-2 inhibitor (-)-gossypol triggers autophagic cell death in malignant glioma. Mol Cancer Res 2010: 1002-1016, 2010.

181. Wardyn JD, Ponsford AH, and Sanderson CM. Dissecting molecular cross-talk between Nrf2 and NF-kappaB response pathways. Biochem Soc Trans 43: 621-626, 2015.

182. Wei Y, Pattingre S, Sinha S, Bassik M, and Levine B. JNK1-mediated phosphorylation of Bcl-2 regulates starvation-induced autophagy. Mol Cell 30: 678-688, 2008.

183. Westermann B. Bioenergetic role of mitochondrial fusion and fission. Biochim Biophys Acta 1817: 1833-1838, 2012.

184. Wilkins HM, Marquardt K, Lash LH, and Linseman DA. $\mathrm{Bcl}-2$ is a novel interacting partner for the 2-oxoglutarate carrier and a key regulator of mitochondrial glutathione. Free Radic Biol Med 52: 410-419, 2012. 
185. Wilson BE, Mochon E, and Boxer LM. Induction of bcl-2 expression by phosphorylated CREB proteins during Bcell activation and rescue from apoptosis. Mol Cell Biol 16: 5546-5556, 1996.

186. Wilson WH, O'Connor OA, Czuczman MS, LaCasce AS, Gerecitano JF, Leonard JP, Tulpule A, Dunleavy K, Xiong H, Chiu YL, Cui Y, Busman T, Elmore SW, Rosenberg SH, Krivoshik AP, Enschede $\mathrm{SH}$, and $\mathrm{Hu}-$ merickhouse RA. Navitoclax, a targeted high-affinity inhibitor of BCL-2, in lymphoid malignancies: a phase 1 dose-escalation study of safety, pharmacokinetics, pharmacodynamics, and antitumour activity. Lancet Oncol 11: 1149-1159, 2010.

187. Wright C, Iyer AK, Kulkarni Y, and Azad N. SNitrosylation of Bcl-2 negatively affects autophagy in lung epithelial cells. J Cell Biochem 117: 521-532, 2016.

188. Yamamoto K, Ichijo $\mathrm{H}$, and Korsmeyer SJ. BCL-2 is phosphorylated and inactivated by an ASK1/Jun Nterminal protein kinase pathway normally activated at G(2)/M. Mol Cell Biol 19: 8469-8478, 1999.

189. Yee YH, Chong SJ, and Pervaiz S. The anti-oxidant and pro-oxidant dichotomy of Bcl-2. Biol Chem 397: 585-593, 2016.

190. Yi X, Yin XM, and Dong Z. Inhibition of Bid-induced apoptosis by Bcl-2. tBid insertion, Bax translocation, and Bax/Bak oligomerization suppressed. J Biol Chem 278: 16992-16999, 2003.

191. Yin XM, Oltvai ZN, and Korsmeyer SJ. BH1 and BH2 domains of Bcl-2 are required for inhibition of apoptosis and heterodimerization with Bax. Nature 369: 321-323, 1994.

192. Zhang J, Wang X, Vikash V, Ye Q, Wu D, Liu Y, and Dong W. ROS and ROS-Mediated Cellular Signaling. Oxid Med Cell Longev 2016: 4350965, 2016.

193. Zhang L, Blackwell K, Altaeva A, Shi Z, and Habelhah H. TRAF2 phosphorylation promotes NF-kappaB-dependent gene expression and inhibits oxidative stress-induced cell death. Mol Biol Cell 22: 128-140, 2011.

194. Zhao M, Eaton JW, and Brunk UT. Bcl-2 phosphorylation is required for inhibition of oxidative stress-induced lysosomal leak and ensuing apoptosis. FEBS Lett 509: 405412, 2001.

195. Zhao W, Fan GC, Zhang ZG, Bandyopadhyay A, Zhou X, and Kranias EG. Protection of peroxiredoxin II on oxidative stress-induced cardiomyocyte death and apoptosis. Basic Res Cardiol 104: 377-389, 2009.

196. Zhong LT, Sarafian T, Kane DJ, Charles AC, Mah SP, Edwards RH, and Bredesen DE. bcl-2 inhibits death of central neural cells induced by multiple agents. Proc Natl Acad Sci U S A 90: 4533-4537, 1993.

197. Zimmermann AK, Loucks FA, Schroeder EK, Bouchard RJ, Tyler KL, and Linseman DA. Glutathione binding to the Bcl-2 homology-3 domain groove: a molecular basis for Bcl-2 antioxidant function at mitochondria. $J$ Biol Chem 282: 29296-29304, 2007.
Address correspondence to: Prof. Shazib Pervaiz

Department of Physiology

Yong Loo Lin School of Medicine National University of Singapore

Singapore 117597

Singapore

E-mail: phssp@nus.edu.sg

Date of first submission to ARS Central, October 18, 2017; date of final revised submission, December 5, 2017; date of acceptance, January 5, 2018.

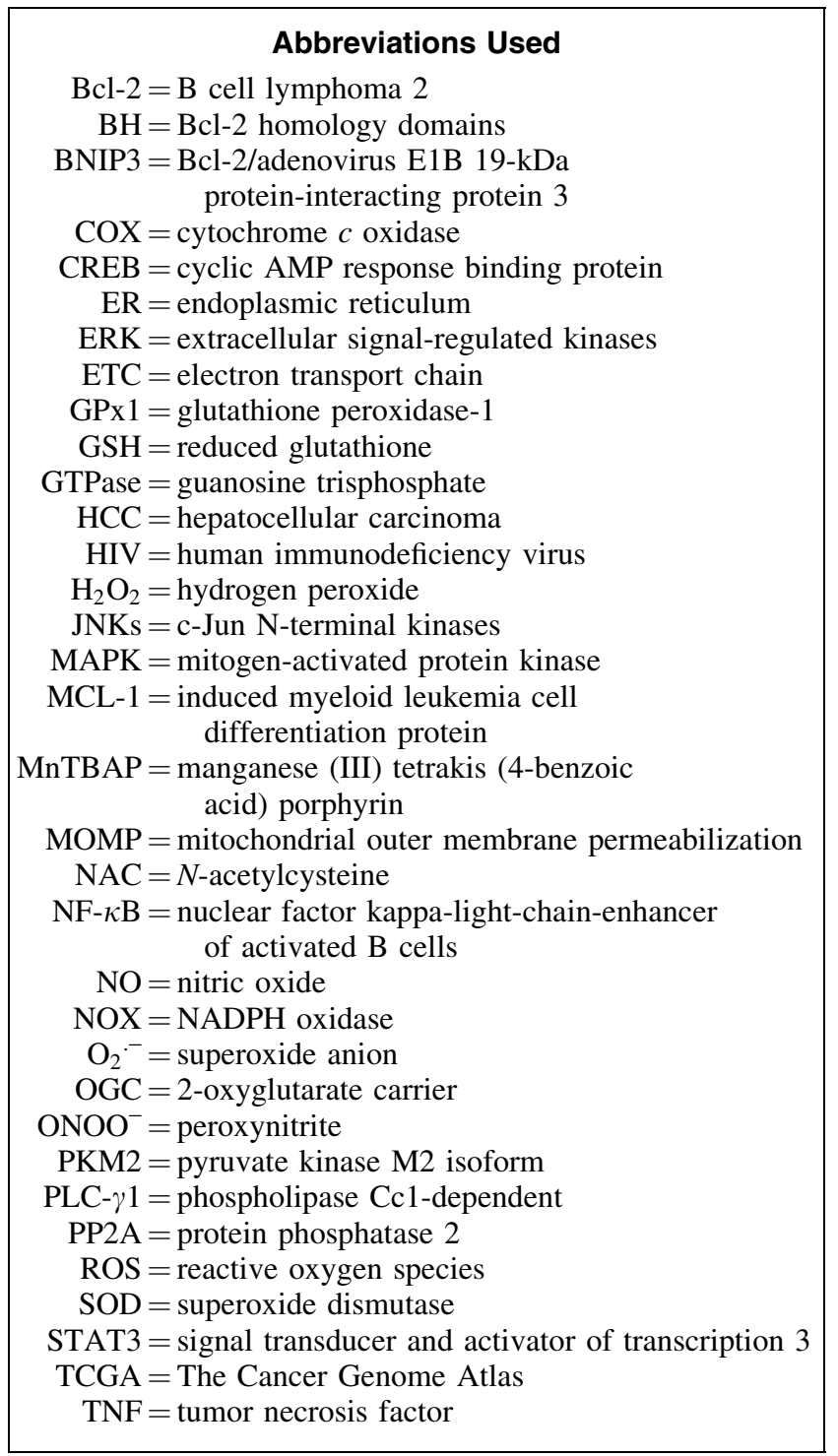

